\title{
Geochemical stages at Jasper Seamount and the origin of intraplate volcanoes
}

\section{J. G. Konter}

Scripps Institution of Oceanography, University of California, San Diego, 9500 Gilman Drive, La Jolla, California 92093-0225, USA

Now at Department of Geological Sciences, University of Texas at El Paso, El Paso, Texas 79968, USA (jgkonter@utep.edu)

\section{H. Staudigel}

Scripps Institution of Oceanography, University of California, San Diego, 9500 Gilman Drive, La Jolla, California 92093-0225, USA

\section{J. Blichert-Toft}

Laboratoire des Sciences de la Terre, Ecole Normale Supérieure de Lyon, F-69364 Lyon CEDEX 7, France

\section{B. B. Hanan}

\author{
Department of Geological Sciences, San Diego State University, San Diego, California 92182-1020, USA
}

\section{Polvé}

Observatoire Midi-Pyrénées, Université Paul Sabatier, F-31400 Toulouse, France

\section{G. R. Davies}

Faculty of Earth and Life Sciences, Vrije Universiteit Amsterdam, 1081 HV Amsterdam, Netherlands

\section{N. Shimizu}

Woods Hole Oceanographic Institution, Woods Hole, Massachusetts 02543-1541, USA

\section{P. Schiffman}

Department of Geology, University of California, Davis, California 95616, USA

[1] Ocean intraplate volcanoes (OIVs) are formed in a sequence of stages, from large to small, that involve a systematic progression in mantle melting in terms of volumes and melt fractions with concomitant distinct mantle source signatures. The Hawaiian volcanoes are the best-known example of this type of evolution, even though they are extraordinarily large. We explore the $\mathrm{Pb}-\mathrm{Sr}-\mathrm{Nd}-\mathrm{Hf}$ isotopic evolution of much smaller OIVs in the Fieberling-Guadalupe Seamount Trail (FGST) and small, near-ridge generated seamounts in the same region. In particular, we investigate whether we can extend the Hawaiian models to Jasper Seamount in the FGST, which displays three distinct volcanic stages. Each stage has characteristic variations in $\mathrm{Pb}-\mathrm{Sr}-\mathrm{Nd}-\mathrm{Hf}$ isotopic composition and trace element enrichment that are remarkably similar to the systematics observed in Hawaii: (1) The most voluminous, basal "shield building" stage, the Flank Transitional Series (FTS), displays slightly isotopically enriched compositions compared to the common component $\mathrm{C}$ and the least enriched trace elements $\left({ }^{143} \mathrm{Nd} /{ }^{144} \mathrm{Nd}: 0.512866-0.512909,{ }^{206} \mathrm{~Pb} /{ }^{204} \mathrm{~Pb}\right.$ : 18.904-19.054; La/Sm: 3.71-4.82). (2) The younger and substantially less voluminous Flank Alkalic Series (FAS) is comparatively depleted in $\mathrm{Sr}, \mathrm{Nd}$, and $\mathrm{Hf}$ isotope compositions plotting on the side of $\mathrm{C}$, 
near the least extreme values for the Austral Islands and St. Helena. Trace elements are highly enriched $\left({ }^{143} \mathrm{Nd} /{ }^{144} \mathrm{Nd}\right.$ : $0.512912-0.512948,{ }^{206} \mathrm{~Pb} /{ }^{204} \mathrm{~Pb}: 19.959-20.185$; La/Sm: 9.24). (3) The Summit Alkalic Series (SAS) displays the most depleted $\mathrm{Sr}, \mathrm{Nd}$, and $\mathrm{Hf}$ isotope ratios and is very close in isotopic composition to the nearby near-ridge seamounts but with highly enriched trace elements $\left({ }^{143} \mathrm{Nd} /{ }^{144} \mathrm{Nd}\right.$ : $\left.0.512999-0.513050,{ }^{206} \mathrm{~Pb} /{ }^{204} \mathrm{~Pb}: 19.080-19.237 ; \mathrm{La} / \mathrm{Sm}: 5.73-8.61\right)$. These data fit well with proposed multicomponent melting models for Hawaii, where source lithology controls melt productivity. We examine the effect of melting a source with dry peridotite, wet peridotite, and pyroxenite, calculating melt productivity functions with depth to evaluate the effect of potential temperature and lithospheric thickness. This type of melting model appears to explain the isotopic variation in a range of small to large OIVs, in particular for OIVs occurring far from the complicating effects of plate boundaries and continental crust, constraining their geodynamic origin.

Components: 13,264 words, 8 figures, 3 tables.

Keywords: Jasper Seamount; geochemistry; isotope; melting model.

Index Terms: 1033 Geochemistry: Intra-plate processes (3615, 8415); 1040 Geochemistry: Radiogenic isotope geochemistry; 3037 Marine Geology and Geophysics: Oceanic hotspots and intraplate volcanism.

Received 10 September 2008; Revised 12 November 2008; Accepted 26 November 2008; Published 3 February 2009.

Konter, J. G., H. Staudigel, J. Blichert-Toft, B. B. Hanan, M. Polvé, G. R. Davies, N. Shimizu, and P. Schiffman (2009), Geochemical stages at Jasper Seamount and the origin of intraplate volcanoes, Geochem. Geophys. Geosyst., 10, Q02001, doi:10.1029/2008GC002236.

\section{Introduction}

[2] The geochemical composition of ocean intraplate volcanoes (OIVs) has played an important role in understanding the Earth as a chemical and dynamical system [e.g., Allègre et al., 1983; Zindler and Hart, 1986]. An important step toward this understanding is provided by the geochemical composition and evolution of individual OIVs. Their composition and evolution is dependent on their mantle source composition and the melting process extracting partial melts from the source. Some of the best-studied examples of such OIVs are the Hawaiian volcanoes, from which a systematic evolution in compositions and melting parameters has been deduced [Stearns, 1940; Macdonald and Katsura, 1964; Macdonald, 1968; Moore et al., 1982; Clague and Dalrymple, 1987; Frey et al., 1990]. Models attempting to explain this evolution have evolved from binary plume-lithosphere mixing models to models involving melting of multiple plume components and an ongoing discussion on the exact role of the lithosphere [e.g., Chen and Frey, 1983, 1985; Roden et al., 1984; Clague and Dalrymple, 1987; Reiners and Nelson, 1998; Lassiter et al., 2000; Yang et al., 2003; Huang et al., 2005; Shafer et al., 2005; Fekiacova et al., 2007]. In order to evaluate the potential of some of these models in other OIVs, it is important to distinguish signatures generated by melting and mixing versus actual mantle source components that relate to the composition and heterogeneity of the Earth's mantle.

[3] Investigations into the mantle source components and melting models of OIV stages have led to the recognition of at least two groups of OIVs [Woodhead, 1992]. One group shows an evolution to more alkalic, isotopically depleted late-stage volcanism (Hawaii, the Societies, Mauritius, Pitcairn), while the other group evolves to isotopically enriched late-stage volcanism (Samoa, Kerguelen, and the Marquesas) [Wright and White, 1987; Woodhead, 1992; Valbracht et al., 1996; White and Duncan, 1996; Ielsch et al., 1998; Paul et al., 2005; Workman et al., 2004]. Explaining the origin of each of these volcanoes is beyond the scope of this paper, but we note that the former group appears to have been formed in tectonically simple areas, whereas Samoa, Kerguelen, and the Marquesas are located in much more complex settings. For example, Samoa is located at a complex strike slip-trench plate boundary, where rejuvenated volcanism has been related to trench rollback [Hart et al., 2004]. In addition, Kerguelen is built on a fragment of continental crust [Frey et al., 2000], and the emplacement of the Marquesas archipelago was likely controlled by plate tectonic features [Legendre et al., 2005]. We will focus on the first group suggested by Woodhead [1992] to be related to deep thermochemical plumes [Morgan, 
1971; Hofmann, 1997], and we investigate whether this model satisfies observations at smaller volcanoes such as those in the Fieberling-Guadalupe Seamount trail (FGST) [Jarrard and Clague, 1977].

[4] Specifically, we focus here on Jasper Seamount, a moderately sized seamount from the FGST, and compare its geochronological, geological, geochemical, and geophysical characteristics to the Hawaiian volcanoes. In addition to examining the scalability of Hawaiian melting models, observations from Jasper Seamount may contribute to ongoing questions about involved processes. Therefore, increasing the observations for the Hawaiian type of OIV at a stage-by-stage level from a range of different volcanoes should help place further constraints on a universal model explaining this type of OIV. In turn, this may lead to the recognition of specific processes related to different types of intraplate volcanism [e.g., Courtillot et al., 2003].

\section{Geology and Regional Tectonic Setting}

[5] Our study area is located on young (33-25 Ma) Pacific oceanic crust south of the Murray Fracture zone, off the coast of Baja California. The nearby transform plate boundary to the East was convergent until $12 \mathrm{Ma}$ ago [Atwater and Severinghaus, 1989; Lonsdale, 1991]. Two seamount types can be distinguished based on size, morphology, and composition: a group of small, scattered seamounts formed near the ridge axis, and a pronounced volcanic lineament of larger seamounts, the FGST (Figure 1).

[6] The near-ridge seamounts include Echo, Linzer, Hop-Sing, and Bonanza (Figure 1) and are very similar to other seamounts located just off the main ridge axis [Batiza and Vanko, 1984]. This type of seamount typically has a small, flattopped morphology, with primitive tholeiitic basal lavas, and may be capped with alkalic basalts [Batiza and Vanko, 1984]. The most enriched rock types have been found off-axis and have a rather large isotopic variability, interpreted to be the result of melting of smaller volumes of mantle and/or low degrees of partial melting and/or less melt aggregation of a heterogeneous mantle source [Batiza and Vanko, 1984; Zindler et al., 1984; Graham et al., 1988; Castillo and Batiza, 1989; Niu et al., 2002]. These near-ridge seamounts may better reflect the degree of heterogeneity in the uppermost mantle.
[7] The second seamount type, defined by the FGST, includes six major volcanoes forming a WNW-ESE trending lineament: Fieberling, Hoke, Flint, Jasper, Opal, and Guadalupe (Figure 1), a smaller version of volcanic chains such as Hawaii and Louisville. FGST seamounts are larger (3$4 \mathrm{~km}$ tall) than the near-ridge seamounts and form solitary volcanoes with minor rift zones. These seamounts are age-progressive $(\sim 80 \mathrm{~km} / \mathrm{Ma}$, Figure 1) with Fieberling at $20.3 \mathrm{Ma}$ and Jasper between 11.5 and 4.1 Ma, while two different crush size fractions of one sample from Opal gave 10.1 and 7.4 Ma; Guadalupe Island was active $7 \mathrm{Ma}$ ago and may still be active [Batiza, 1977; Batiza et al., 1979; Lonsdale, 1991; Pringle et al., 1991; Gee et al., 1991; Davis et al., 2002]. San Quentín volcanic field, Baja California, has been suggested as a continuation [Storey et al., 1989; Luhr et al., 1995], even though this field is located $>200 \mathrm{~km}$ to the north of the extrapolated trail. Although discrepancies exist between predicted ages and measured ages (Figure 1), these are minor considering that volcanism on Jasper lasted for about $7 \mathrm{Ma}$ and that it is quite likely that the marine-based sampling was insufficient to recover the oldest volcanic phase presumably making up the cores of the seamounts.

\section{Geology and Structure of Jasper Seamount}

[8] Jasper Seamount $\left(30^{\circ} 27^{\prime} \mathrm{N}, 122^{\circ} 44^{\prime} \mathrm{W}\right)$ rises from the seafloor at $4000 \mathrm{~m}$ to $700 \mathrm{~m}$ depth, with a total volume of $\sim 690 \mathrm{~km}^{3}$, and is slightly elongated in the northeast-southwest direction due to minor rift zones (Figure 2). The internal structure of Jasper Seamount has been explored by active source seismic tomography [Hildebrand et al., 1989; Hammer et al., 1994], gravity [Hammer et al., 1991], and magnetic anomaly inversions [Gee et al., 1988]. In addition, geochronological, petrological, and rock magnetic studies on samples from 18 dredges from the flanks and summits were carried out (Figure 2; not all dredges shown) [Pringle et al., 1991; Gee et al., 1991]. Jointly, these data place Jasper Seamount among the beststudied submarine intraplate volcanoes.

[9] Sample descriptions and geophysical data suggest that Jasper Seamount is made of pillow lavas, gabbros, and dikes at depth and volcaniclastics near the summit [Gee et al., 1991]. Three major rock series have been recognized based on major element data and modeling [Gee et al., 1991]. Summit dredges yielded abundant volcaniclastics 

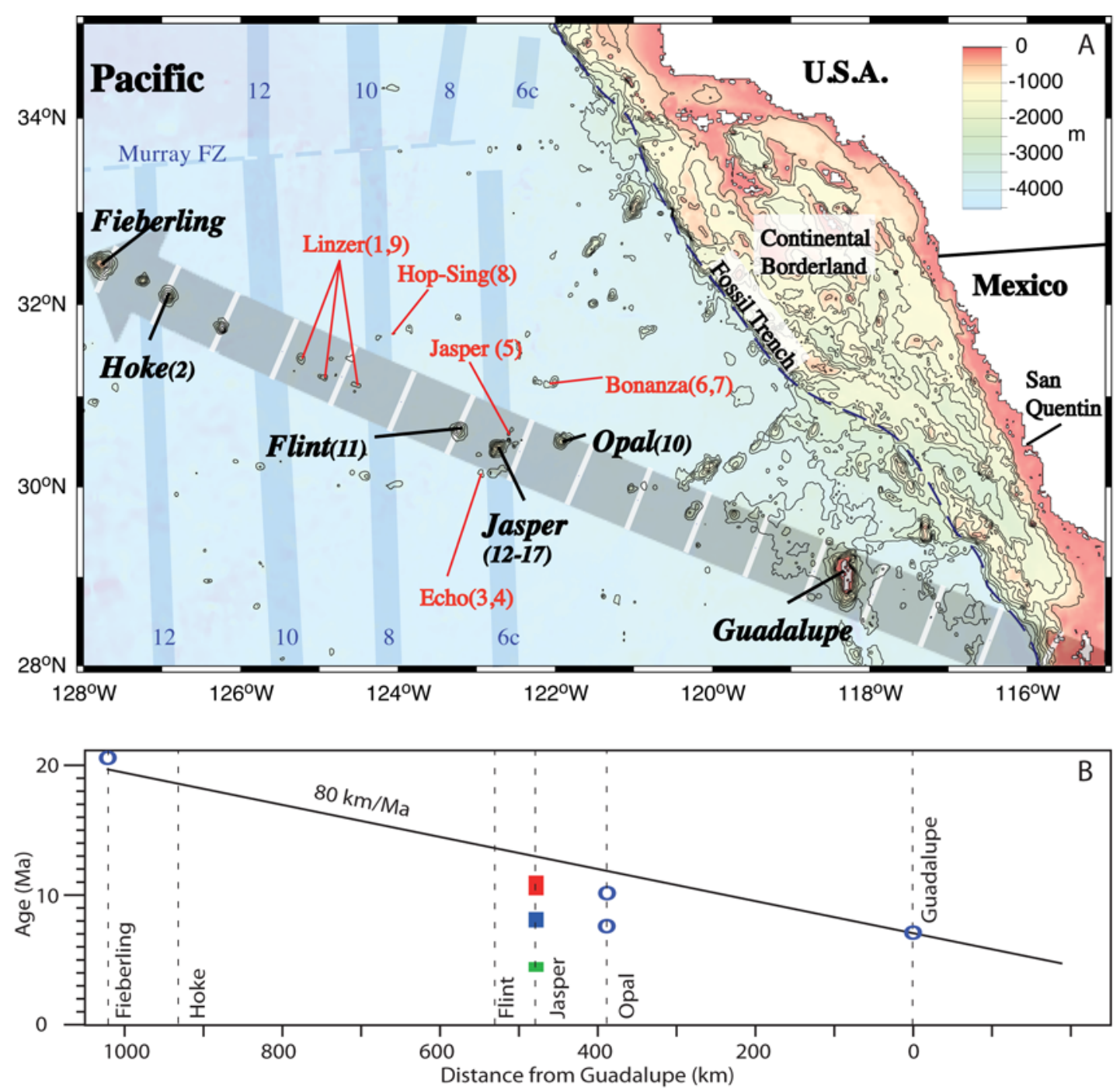

Figure 1. (a) Bathymetric map of the Eastern Pacific seafloor off California (USA) and Baja California (Mexico) from Smith and Sandwell [1997]. Sample locations from two groups of seamounts are shown: small, near-ridge seamounts (labeled in red, with sample numbers in parentheses) and the Fieberling-Guadalupe Seamount Trail (FGST; names and sample numbers in black). The shaded arrow indicates the absolute Pacific plate motion from Koppers et al. [2001], whereby subdivisions represent 1 Ma time steps. Simplified magnetic anomalies are given as blue stripes, with an offset at the Murray Fracture Zone [after Atwater and Severinghaus, 1989]. Contours are drawn at every $500 \mathrm{~m}$ between $4000 \mathrm{~m}$ and $0 \mathrm{~m}$ depth. (b) Age-distance plot for FGST, where colored bars indicate periods of activity at Jasper Seamount. Circles indicate available ages for other FGST volcanoes. Age data fit reasonably well with plate motion. Age data from Batiza [1977], Batiza et al. [1979], Lonsdale [1991], Pringle et al. [1991], Gee et al. [1991], Davis et al. [2002].

and the most alkalic lavas (Summit Alkali Series (SAS); green bars in Figure 2 and green field in Figure 3). Dredges from the upper flanks of Jasper yielded lavas of intermediate alkalinity (Flank Alkalic Series (FAS); blue bars in Figure 2 and blue fields in Figure 3), and the deepest dredges yielded basalt that are transitional to tholeiitic (Flank Transitional Series (FTS); red bars in Figure 2 and red fields in Figure 3). These three groups make up distinct groups in major and trace element compositions (e.g., $\mathrm{Na}_{2} \mathrm{O}+\mathrm{K}_{2} \mathrm{O}$ versus $\mathrm{SiO}_{2}$; Figure 3 ), and in normative projections and radiogenic ages [Gee et al., 1991]. Major element trends $\left(\mathrm{CaO} / \mathrm{Al}_{2} \mathrm{O}_{3}\right.$ and $\mathrm{TiO}_{2}$ versus $\left.\mathrm{MgO}\right)$ indicate clinopyroxene, plagioclase, and Ti-bearing oxide fractionation, while normative projections demonstrate low-pressure fractionation during FTS, with higher-pressure fractionation during the alkalic stages (particularly FAS) [Gee et al., 1991]. Prevalence of crustal over mantle xenoliths in SAS 


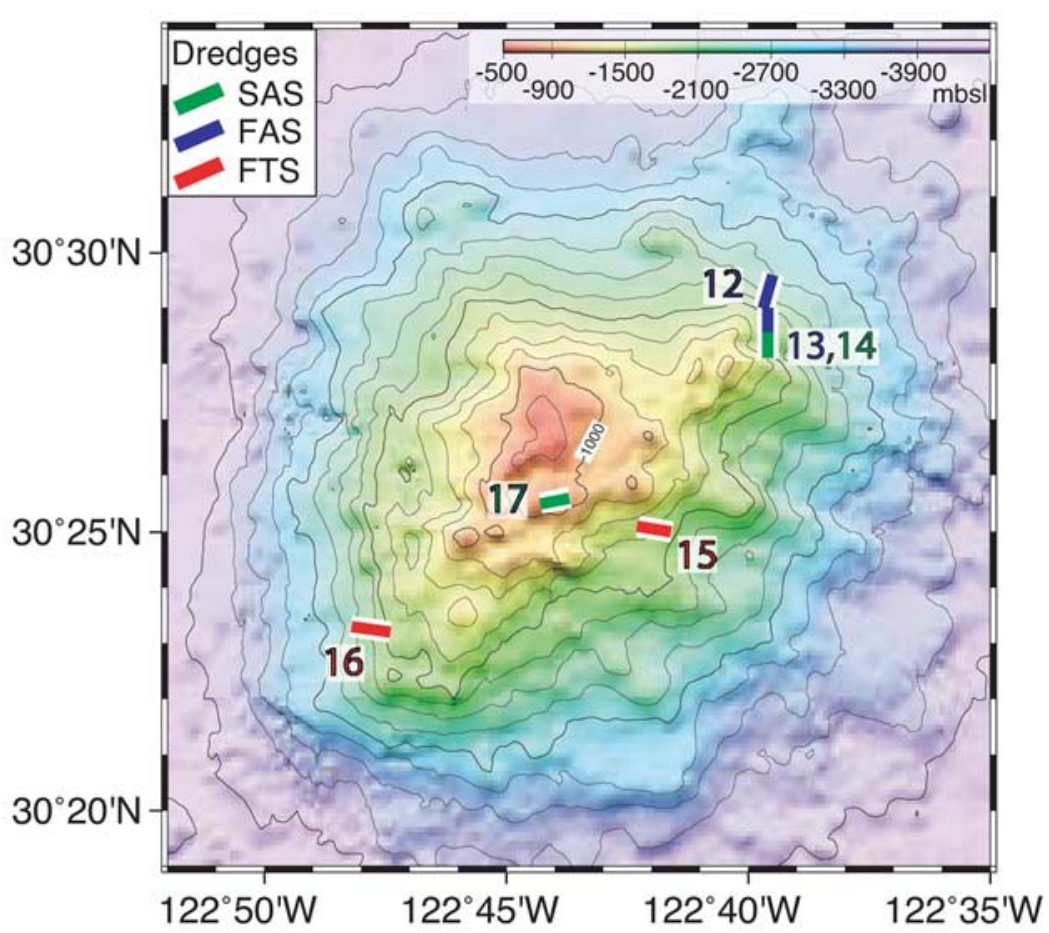

Figure 2. Overview of Jasper Seamount from gridded multibeam data. The seamount summit is slightly elongated NE-SW and shows several small rifts. The seamount rises from about $4000 \mathrm{~m}$ to $700 \mathrm{~m}$ depth (contours every $250 \mathrm{~m}$ ). Large labeled numbers indicate sample numbers. Colored bars show dredge tracks and color indicates grouping in stages.

suggests fractionation occurred near the crust-mantle boundary. Gee et al. [1991] further estimated that the FTS makes up more than $90 \%$ of the total volume of Jasper, while FAS makes up about 6\% and the youngest SAS makes up less than $1 \%$ of the volcano.

[10] The timing of Jasper Seamount's magmatic progression is better constrained than for most other seamounts due to the high sampling density of this seamount, geophysical models of its internal structure and age dating of several samples per stage. Nine representative ages for the three eruptive series [Pringle et al., 1991] combined with geomagnetic modeling [Gee et al., 1988], constrain its volcanic activity. The results suggest a stagewise construction of Jasper Seamount, similar to Hawaiian stages. Although the volume of Jasper Seamount is 1/50th of a Hawaiian volcano, Hawaiian volcanoes also consist of a main shield (95-98\%), a postshield $(\sim 1 \%)$, and a rejuvenated $(<1 \%)$ series [Bargar and Jackson, 1974, Clague and Dalrymple, 1987]. The shield-building FTS erupted between 11.5 Ma and 10.0 Ma $(\mathrm{N}=2)$, the postshield FAS between 8.7 and $7.5 \mathrm{Ma}(\mathrm{N}=4)$, and the rejuvenated SAS between 4.8 and $4.1 \mathrm{Ma}$ $(\mathrm{N}=3)$. For comparison, volcanism in Hawaii for the shield stages lasts about $0.5-2 \mathrm{Ma}$, for the postshield stage about $0.5 \mathrm{Ma}$, and for the rejuvenated stage between about 0.25 to $>2 \mathrm{Ma}$ after about $1 \mathrm{Ma}$ of quiescence [Clague and Dalrymple, 1987]. This stage-wise progression containing a less tholeiitic shield than Hawaii is common in many OIVs [e.g., Hoernle and Schmincke, 1993; Maaloe, 1998; Geldmacher et al., 2001; Paul et al., 2005].

\section{Sample Description}

[11] The Jasper Seamount samples analyzed in this study constitute a representative subset of a larger sample collection described and analyzed by Gee et al. [1991]. Samples from the surrounding seamounts were obtained by manned submersible (Woods Hole Oceanographic Institution, Alvin dive numbers 1465-1468, 1471, 1474, and 1475). Sample details, including sample locations, are provided in Table 1, and sample compositions are provided in Tables $2-3$, while duplicate analyses and supplemental sample data can be found in Tables $\mathrm{S} 1-\mathrm{S} 5$ in the auxiliary material. ${ }^{1}$

${ }^{1}$ Auxiliary materials are available in the HTML. doi:10.1029/ 2008GC002236. 


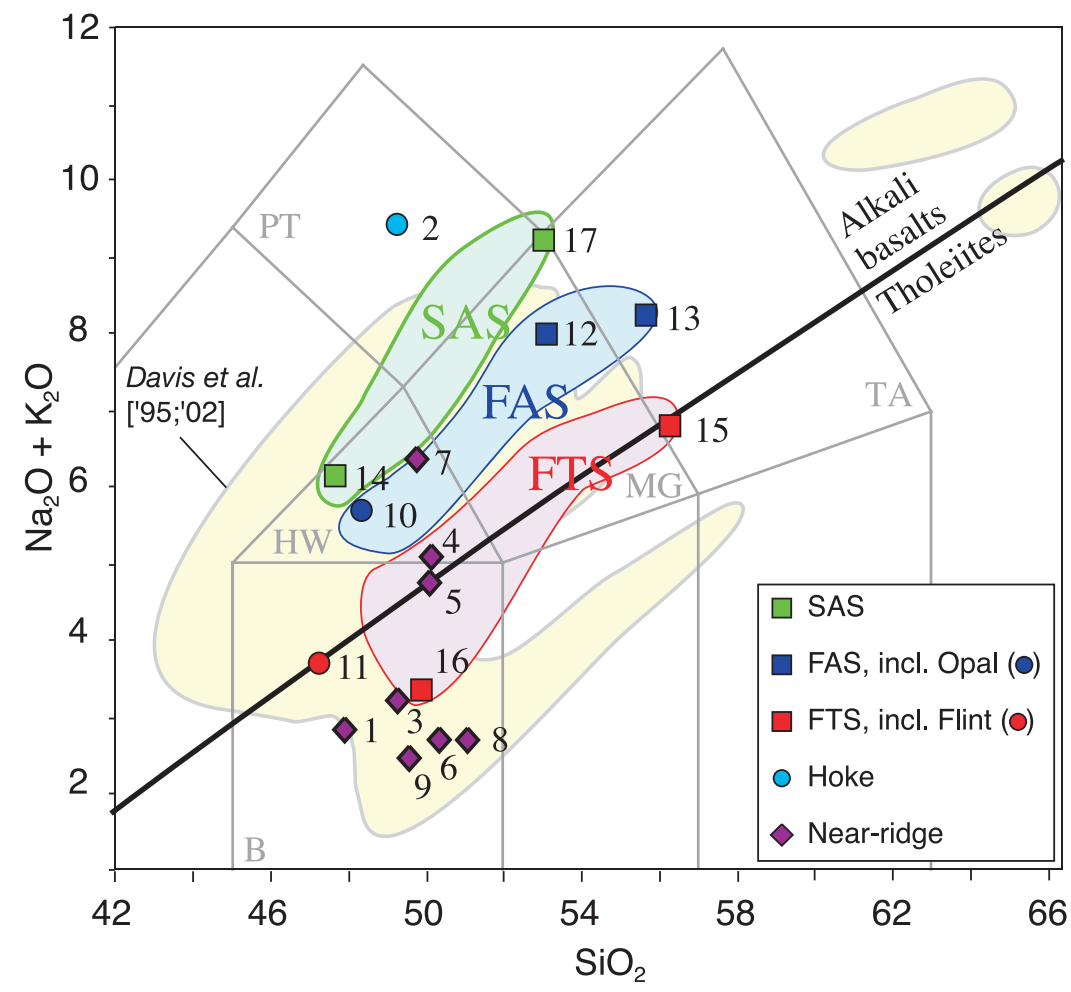

Figure 3. $\mathrm{Na}_{2} \mathrm{O}+\mathrm{K}_{2} \mathrm{O}$ variation versus $\mathrm{SiO}_{2}$ from bulk rock samples of seamounts in the Eastern Pacific. Symbols for samples analyzed are given in the legend and sample numbers correspond to numbers in Table 1. Jasper Seamount samples are grouped into three distinct series (SAS: green, FAS: blue, and FTS: red; groups after Gee et al. [1991]) that form trends parallel to the Tholeiite-Alkali Basalt separation line from Irvine and Baragar [1971] and overlap to some extent with the California borderland seamounts of Davis et al. [1995, 2002] (yellow field). Near-ridge seamounts (purple diamonds) show a rather limited variation in $\mathrm{SiO}_{2}$ but substantial variation in total alkalies. Classification after Le Bas et al. [1986]. Key: B, basalts; HW, hawaiite; MG, mugearite; TA, trachy-andesite; PT, phonolitic tephrite.

[12] We chose two representative samples for each of the three eruptive series at Jasper and several samples from surrounding seamounts. Their major element compositions overlap with the range found previously for other seamounts in the area by Davis et al. [1995, 2002] (Figure 3, yellow field). Sample numbers are included in Figure 3 to illustrate which group each sample belongs to.

[13] Near-ridge seamounts yielded tholeiitic basalts from Linzer (samples 1, 9), Echo (3), Bonanza (6), and Hop-Sing (8); transitional basalts from Echo (4) and Jasper Satellite (5); and a hawaiite from Bonanza (7). For Jasper Seamount, samples from SAS consist of a hawaiite (14) and a trachyandesite (17); from FAS samples consist of a mugearite (12) and trachy-andesite (13); and from FTS samples consist of a tholeiitic basalt (16) and a trachy-andesite (15). Other samples from FGST are a hawaiite from Opal (10) and a transitional basalt from Flint (11), similar to FAS and FTS, respectively, in terms of major elements. We also studied a phonolitic tephrite from Hoke (2). Most samples are sparsely phyric with olivine and plagioclase phenocrysts. Groundmass and more rare phenocrysts are olivines, pyroxenes, plagioclase, spinel, amphibole, and biotite. Especially the SAS has abundant xenocrysts and crustal and mantle xenoliths. All bulk rock samples have experienced submarine weathering, but are relatively fresh when compared to other submarine basalts [e.g., Hauff et al., 2003; Koppers et al., 2003]. Many samples analyzed here contain some fresh glass and only partly replaced olivine. More detailed petrographic descriptions and modeling are given by Gee et al. [1991], and major element compositions are listed in Table S6 in the auxiliary material.

\section{Methods}

[14] We report analyses of trace element and isotopic compositions for a range of samples from Jasper Seamount and other seamounts in the area. Isotopic analyses were carried out on leached 
Table 1. Geographical Data

\begin{tabular}{|c|c|c|c|c|c|c|c|}
\hline $\begin{array}{l}\text { Sample } \\
\text { ID }\end{array}$ & $\begin{array}{l}\text { Sample } \\
\text { Name }\end{array}$ & $\begin{array}{l}\text { Latitude } \\
\text { Decimal }\end{array}$ & $\begin{array}{l}\text { Longitude } \\
\text { Decimal }\end{array}$ & Depth & $\begin{array}{l}\text { Location } \\
\text { Description }\end{array}$ & $\begin{array}{c}\text { Jasper Seamount } \\
\text { Stage }\end{array}$ & $\begin{array}{l}\text { Sampling } \\
\text { Method }\end{array}$ \\
\hline 1 & $14657-1$ & $31.22^{\circ} \mathrm{N}^{\mathrm{b}}$ & $125.92^{\circ} \mathrm{W}^{\mathrm{b}}$ & 2938 & Linzer & N/A & Alvin dive \\
\hline 2 & $14669-1$ & $32.08^{\circ} \mathrm{N}^{\mathrm{b}}$ & $126.92^{\circ} \mathrm{W}^{\mathrm{b}}$ & 1440 & Hoke Seamount & N/A & Alvin dive \\
\hline 3 & $14672-1$ & $30.14^{\circ} \mathrm{N}^{\mathrm{b}}$ & $122.93^{\circ} \mathrm{W}^{\mathrm{b}}$ & 3878 & Echo & N/A & Alvin dive \\
\hline 4 & $14685-1$ & $30.18^{\circ} \mathrm{N}^{\mathrm{b}}$ & $122.77^{\circ} \mathrm{W}^{\mathrm{b}}$ & 3129 & Echo & N/A & Alvin dive \\
\hline 5 & $14711-2$ & $30.52^{\circ} \mathrm{N}^{\mathrm{b}}$ & $122.43^{\circ} \mathrm{W}^{\mathrm{b}}$ & 3613 & Jasper Satellite & N/A & Alvin dive \\
\hline 6 & $14746-1$ & $31.15^{\circ} \mathrm{N}^{\mathrm{b}}$ & $122.20^{\circ} \mathrm{W}^{\mathrm{b}}$ & 2920 & Bonanza & N/A & Alvin dive \\
\hline 7 & $14757-1$ & $31.13^{\circ} \mathrm{N}^{\mathrm{b}}$ & $122.10^{\circ} \mathrm{W}^{\mathrm{b}}$ & 2869 & Bonanza & N/A & Alvin dive \\
\hline 8 & BONZ 1-1 & $\begin{array}{l}31.717^{\circ} \mathrm{N}- \\
31.720^{\circ} \mathrm{N}\end{array}$ & $\begin{array}{l}123.818^{\circ} \mathrm{W}- \\
123.822^{\circ} \mathrm{W}\end{array}$ & $3270-2705$ & Hop-Sing & N/A & Dredge \\
\hline 9 & BONZ 5-1 & $\begin{array}{l}31.188^{\circ} \mathrm{N}- \\
31.213^{\circ} \mathrm{N}\end{array}$ & $\begin{array}{l}124.910^{\circ} \mathrm{W}- \\
124.900^{\circ} \mathrm{W}\end{array}$ & & Linzer & N/A & Dredge \\
\hline 10 & CRAT 9-1 & $30.500^{\circ} \mathrm{N}$ & $121.913^{\circ} \mathrm{W}$ & 1350 & Opal Seamount & similar to FAS & Dredge \\
\hline 11 & D21-3 & $\begin{array}{r}30.610^{\circ} \mathrm{N}- \\
30.608^{\circ} \mathrm{N}\end{array}$ & $\begin{array}{l}122.218^{\circ} \mathrm{W}- \\
122.218^{\circ} \mathrm{W}\end{array}$ & 1455 & Flint Seamount & similar to FTS & Dredge \\
\hline 12 & JS 1-8 & $\begin{array}{r}30.493^{\circ} \mathrm{N}- \\
30.483^{\circ} \mathrm{N}\end{array}$ & $\begin{array}{l}122.658^{\circ} \mathrm{W}- \\
122.662^{\circ} \mathrm{W}\end{array}$ & $2750-2050$ & Jasper Seamount & FAS & Dredge \\
\hline 12 & JS 1-8-Bt & $\begin{array}{l}30.493^{\circ} \mathrm{N}- \\
30.483^{\circ} \mathrm{N}\end{array}$ & $\begin{array}{l}122.658^{\circ} \mathrm{W}- \\
122.662^{\circ} \mathrm{W}\end{array}$ & $2750-2050$ & Jasper Seamount & FAS & Dredge \\
\hline 13 & JS $2-3$ & $\begin{array}{l}\left(30.483^{\circ} \mathrm{N} \text { and }\right. \\
\left.30.482^{\circ} \mathrm{N}\right)- \\
\left(30.468^{\circ} \mathrm{N}\right. \\
\left.\text { and } 30.468^{\circ} \mathrm{N}\right)^{\mathrm{c}}\end{array}$ & $\begin{array}{l}\left(122.660^{\circ} \mathrm{W} \text { and }\right. \\
\left.122.665^{\circ} \mathrm{W}\right)- \\
\left(122.660^{\circ} \mathrm{W}\right. \\
\left.\text { and } 122.655^{\circ} \mathrm{W}\right)^{\mathrm{c}}\end{array}$ & $2100-1900$ & Jasper Seamount & FAS & Dredge \\
\hline 14 & JS $2-5$ & $\begin{array}{l}\left(30.483^{\circ} \mathrm{N} \text { and }\right. \\
\left.30.482^{\circ} \mathrm{N}\right)- \\
\left(30.468^{\circ} \mathrm{N}\right. \\
\left.\text { and } 30.468^{\circ} \mathrm{N}\right)^{\mathrm{c}}\end{array}$ & $\begin{array}{l}\left(122.660^{\circ} \mathrm{W} \text { and }\right. \\
\left.122.665^{\circ} \mathrm{W}\right)- \\
\left(122.660^{\circ} \mathrm{W}\right. \\
\left.\text { and } 122.655^{\circ} \mathrm{W}\right)^{\mathrm{c}}\end{array}$ & $2100-1900$ & Jasper Seamount & SAS & Dredge \\
\hline 15 & JS 4-7 & $\begin{array}{l}30.417^{\circ} \mathrm{N}- \\
30.418^{\circ} \mathrm{N}\end{array}$ & $\begin{array}{l}122.693^{\circ} \mathrm{W}- \\
122.705^{\circ} \mathrm{W}\end{array}$ & $1825-1660$ & Jasper Seamount & FTS & Dredge \\
\hline 16 & JS 5-19 & $\begin{array}{r}30.388^{\circ} \mathrm{N}- \\
30.387^{\circ} \mathrm{N}\end{array}$ & $\begin{array}{l}122.803^{\circ} \mathrm{W}- \\
122.790^{\circ} \mathrm{W}\end{array}$ & $2500-1925$ & Jasper Seamount & FTS & Dredge \\
\hline 17 & JS $12-4$ & $\begin{array}{r}30.427^{\circ} \mathrm{N}- \\
30.425^{\circ} \mathrm{N}\end{array}$ & $\begin{array}{r}122.728^{\circ} \mathrm{W}- \\
122.738^{\circ} \mathrm{W}\end{array}$ & $950-840$ & Jasper Seamount & SAS & Dredge \\
\hline
\end{tabular}

Table 2. Trace Element Composition of Glasses ${ }^{\mathrm{a}}$

\begin{tabular}{|c|c|c|c|c|c|}
\hline $\begin{array}{l}\text { Sample ID } \\
\text { and Name }\end{array}$ & $13 / \mathrm{JS} 2-3$ & $14 / \mathrm{JS} 2-5$ & $15 / \mathrm{JS} 4-7$ & 16/JS5-19 & $17 / \mathrm{JS} 12-4$ \\
\hline $\mathrm{V}$ & 136 & 346 & 7.90 & 323 & 106 \\
\hline $\mathrm{Cr}$ & 16.9 & 106 & 11.5 & 259 & 15.9 \\
\hline $\mathrm{Rb}$ & 47.8 & 35.2 & 36.2 & 11.3 & 62.3 \\
\hline $\mathrm{Sr}$ & 402 & 814 & 263 & 300 & 705 \\
\hline $\mathrm{Be}$ & 4.53 & 2.43 & 3.29 & 0.722 & 4.55 \\
\hline $\mathrm{Y}$ & 25.6 & 31.7 & 72.2 & 23.0 & 35.1 \\
\hline $\mathrm{Zr}$ & 411 & 328 & 506 & 98.9 & 585 \\
\hline $\mathrm{Nb}$ & 116 & 80.8 & 63.3 & 14.6 & 132 \\
\hline B & 15.6 & 4.96 & 4.64 & 1.72 & 9.24 \\
\hline $\mathrm{Ba}$ & 304 & 436 & 532 & 113 & 621 \\
\hline $\mathrm{La}$ & 81.0 & 46.1 & 58.3 & 10.5 & 77.9 \\
\hline $\mathrm{Ce}$ & 159 & 95.6 & 134 & 22.4 & 154 \\
\hline $\mathrm{Nd}$ & 46.0 & 36.6 & 58.5 & 7.92 & 46.1 \\
\hline $\mathrm{Sm}$ & 8.77 & 8.05 & 15.7 & 2.18 & 9.05 \\
\hline $\mathrm{Ti}$ & 11445 & 19055 & 9013 & 9193 & 13867 \\
\hline $\mathrm{Li}$ & 13.8 & 3.59 & 17.3 & 3.92 & 11.6 \\
\hline Dy & 6.21 & 6.24 & 15.8 & 2.06 & 4.42 \\
\hline Er & 3.48 & 3.33 & 8.83 & 1.33 & 2.45 \\
\hline $\mathrm{Yb}$ & 3.66 & 3.41 & 9.14 & 1.17 & 2.37 \\
\hline
\end{tabular}

\footnotetext{
${ }^{\mathrm{a}}$ Concentrations are measured in $\mathrm{ppm}$.
} 


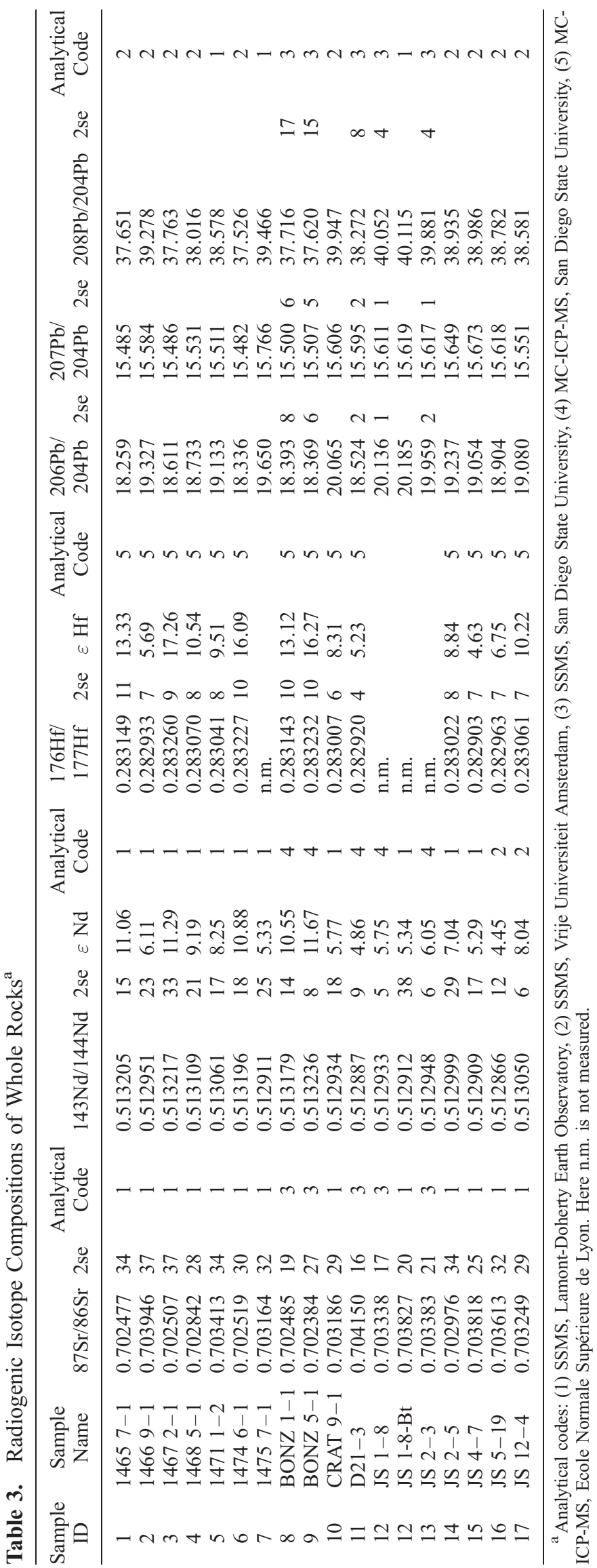


whole rocks, while trace element abundances were obtained from glasses.

[15] Bulk rock samples were prepared using methods avoiding any contact with metal and crushing in an agate mill. Glass chips were picked from gently crushed and washed rocks, set in epoxy resin, and prepared as polished thin sections.

[16] Glass chips, where available, were analyzed for all eruptive series at Jasper Seamount $(\mathrm{N}=5)$ with a Cameca $3 \mathrm{~F}$ ion microprobe at Woods Hole Oceanographic Institution (WHOI), following the procedure of Shimizu and Hart [1982]. For each sample, three spots were analyzed and the average spot data are presented in Table 2. Measurements of the standard KL2G were used for calibration. The estimated uncertainty on this method is less than $\sim 10 \%$ [Shimizu and Hart, 1982], although multiple spots within a given glass chip typically have a relative standard deviation of $<5 \%(1 \sigma)$.

[17] To minimize alteration effects on bulk rock isotope analyses, it is common practice to leach rocks prior to analysis. On the basis of our own experience and on results in the literature, we used $\mathrm{HCl}$ as the leaching reagent and followed a procedure that is commonly used and has been shown to be successful at restoring isotopic compositions in moderately altered basalts [Shimizu and Hart, 1973; Cheng et al., 1987; Staudigel et al., 1991; Pringle, 1992; Castillo et al., 1992; Koppers et al., 1995; Koppers et al., 2003; Regelous et al., 2003; Huang et al., 2005]. This method consisted in leaching the splits of powder taken for isotopic analysis with hot $6 \mathrm{~N} \mathrm{HCl}$ in an ultrasonic bath for one hour. All materials were rinsed in distilled water and dried subsequent to leaching. Analyses performed at later times at different laboratories were preceded by brief ( $\sim 5-10 \mathrm{~min})$ leaching of the previously treated materials.

[18] Isotopic compositions were determined over a time period of 15 years at four different laboratories (chronologically Lamont, Free University Amsterdam, ENS Lyon, San Diego State University; see auxiliary material). We report $\mathrm{Sr}, \mathrm{Nd}, \mathrm{Pb}$, and $\mathrm{Hf}$ isotope data (Table 3). To check for potential interlaboratory biases and time-dependent changes, all analytical sessions included frequent measurements of standards and duplicate analyses to assure consistent laboratory reproducibility within the $2 \sigma$ level. Repeat analyses of samples run at up to three different laboratories (see auxiliary material) show that most sample measurements are within error of each other, except for some of the $\mathrm{Sr}$ isotope compositions that may vary slightly beyond the $3 \sigma$ level. These differences may be due to a range of factors other than analytical uncertainties, such as differences in the leaching efficiency between different sample splits or sample heterogeneity.

\section{Results}

[19] The trace element and isotopic compositions of the FGST are summarized in Tables 2-3 and plotted in Figures $4-8$. We note that petrography and major element analyses for most of these samples were published and interpreted by Gee et al. [1991], and will not be repeated here.

\subsection{Trace Elements}

[20] The trace element abundances from Jasper Seamount show a wide range of enrichment with respect to primitive mantle (Figure 4). The alkalic samples from the FAS and SAS display the steepest slopes, while the transitional samples from the FTS have patterns that are less steep; $\mathrm{La} / \mathrm{Yb}$ ranges from 13.5 to 32.8 in FAS and SAS to $6.38-9.00$ in FTS, while $\mathrm{La} / \mathrm{Sm}$ ranges from 5.74 to 9.24 in FAS and SAS to 3.71-4.81 in the FTS. The slopes of the FTS samples are similar, but sample FTS-15 has higher abundances and significant negative anomalies for $\mathrm{Sr}$ and $\mathrm{Ti}$. The most trace element enriched sample from FAS shows a similar negative $\mathrm{Sr}$ anomaly and a small negative Ti anomaly. This agrees well with the major element interpretation of Gee et al. [1991] such that the most trace element enriched samples within each group can be explained with fractionation of clinopyroxene, plagioclase, and Ti-bearing oxides. Fractionation did not occur at the same pressure for all stages, but the most trace element enriched samples can be explained by up to $85 \%$ fractional crystallization of these phases [Gee et al., 1991].

\subsection{Radiogenic Isotopes}

[21] The data from FGST (solid squares and circles) and the near-ridge seamounts (filled diamonds) are plotted in Figures 5-6 show a significant range in isotopic compositions. The FGST lavas range between 0.512866 and 0.513050 for ${ }^{143} \mathrm{Nd} /{ }^{144} \mathrm{Nd}, 0.282903$ and 0.283061 for ${ }^{176} \mathrm{Hf} /{ }^{177} \mathrm{Hf}, 0.702976$ and 0.704150 for ${ }^{87} \mathrm{Sr} /{ }^{86} \mathrm{Sr}$, 18.524 and 20.185 for ${ }^{206} \mathrm{~Pb} /{ }^{204} \mathrm{~Pb}, 15.551$ and 15.673 for ${ }^{207} \mathrm{~Pb} /{ }^{204} \mathrm{~Pb}$, and 38.272 and 40.115 for ${ }^{208} \mathrm{~Pb} /{ }^{204} \mathrm{~Pb}$. The near-ridge seamounts (filled diamonds) nearly all plot inside the field for Pacific 


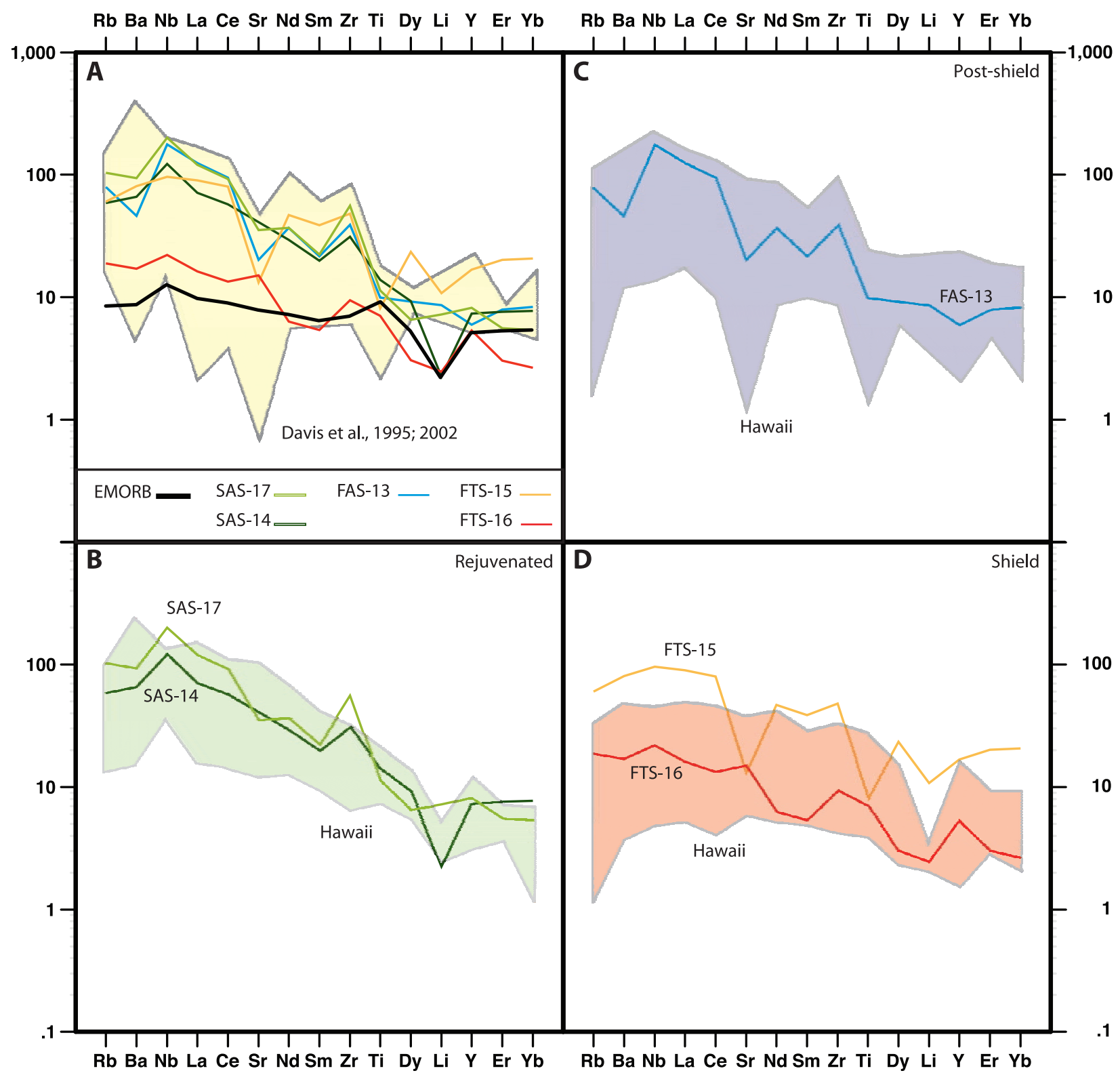

Figure 4. (a) Primitive mantle-normalized trace element abundance patterns of Jasper Seamount (the SAS, the FAS and the FTS; Primitive mantle after McDonough and Sun [1995]). The late stages of Jasper (SAS/FAS: samples 13, $14,17)$ are distinctly steeper than the shield stage, which is more depleted (FTS: sample 16), where the color codes of the stages are as in Figure 3. FTS sample 15 is parallel to sample 16 and was likely subjected to more substantial fractional crystallization (Figure 3 and Gee et al. [1991]). In detail, low $\mathrm{Sr}$ and $\mathrm{Ti}$ values also agree with more substantial fractional crystallization for sample 15 . This shows that more differentiated lavas do not necessarily have steeper patterns, and thus have similar trace element ratios. Note that the seamounts of Davis et al. [1995, 2002] show a similar range to Jasper Seamount and also that SAS is more enriched than EMORB [Sun and McDonough, 1989]. Jasper Seamount samples show enriched (b) rejuvenated and (c) postshield stages compared to (d) the shields stage and show a general correspondence in enrichment with Hawaiian stages. Hawaiian fields from Georoc (http:// georoc.mpch-mainz.gwdg.de/georoc/), excluding outliers.

MORB and the field defined by Davis et al. [1995, 2002] (open diamonds; Figures 5-6).

[22] The FGST forms a cluster in Sr, Nd, Hf, and $\mathrm{Pb}$ isotope space, which is close to prevalent mantle (PREMA) [Zindler and Hart, 1986], the focal zone of OIVs (FOZO) [Hart et al., 1992], or the common component (C) [Hanan and Graham, 1996]. In the following, we will refer to this intermediate composition as $\mathrm{C}$. 


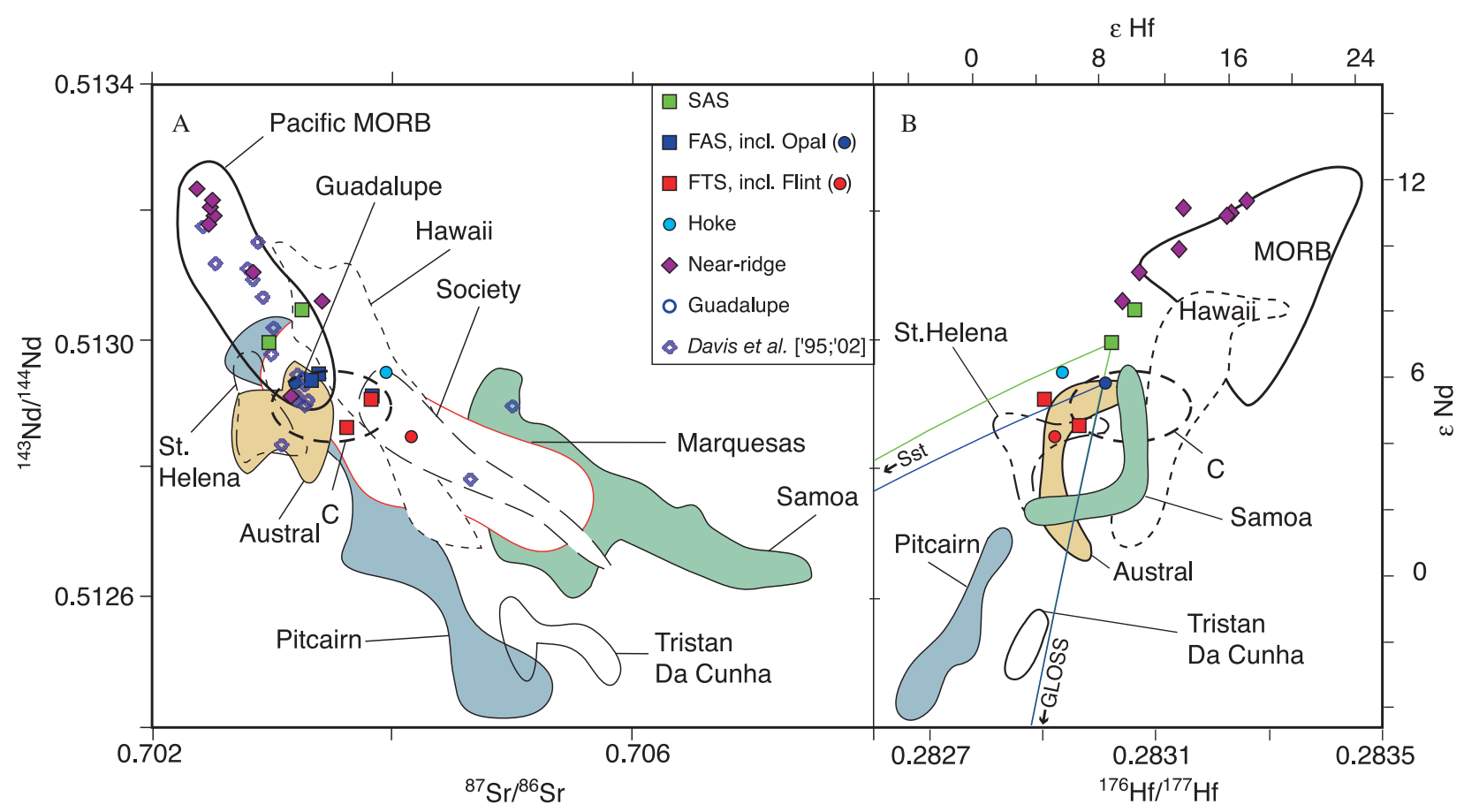

Figure 5. Sr-Nd-Hf isotopic compositions of our samples in comparison with the oceanic basalt array. (a) ${ }^{87} \mathrm{Sr} /{ }^{86} \mathrm{Sr}$ versus ${ }^{143} \mathrm{Nd} /{ }^{144} \mathrm{Nd}$. Jasper Seamount samples span a significant range of the total range known for OIVs (colored and outlined fields), though they cluster at intermediate compositions, showing an elongated field. Different eruptive stages are isotopically distinct, with FTS the most isotopically enriched, FAS intermediate and SAS the most depleted. Samples from FAS closely resemble Guadalupe Island in composition. Flint and Opal Seamounts fit in one of the eruptive stages, while Hoke Seamount combines an isotopically intermediate signature with the most enriched trace element pattern. Near-ridge seamounts overlap with seamounts studied by Davis et al. [1995, 2002] and span a continuous range between depleted MORB and C. (b) ${ }^{176} \mathrm{Hf} /{ }^{177} \mathrm{Hf}$ isotopes also correlate linearly with ${ }^{143} \mathrm{Nd} /{ }^{144} \mathrm{Nd}$ and span a large range in isotopic space, where each of the stages defines a distinct cluster. The slightly enriched FTS isotopic composition is likely a source characteristic, since rough mixing calculations suggest average subducted sediment (GLOSS) [Plank and Langmuir, 1998; Chauvel et al., 2008] would result in higher ${ }^{176} \mathrm{Hf} /{ }^{177} \mathrm{Hf}$ for a given ${ }^{143} \mathrm{Nd} /{ }^{144} \mathrm{Nd}$. Mixes with average sandstone [Condie, 1993; Chauvel et al., 2008] could produce FTS-like composition, but sandstones are unlikely to be present in large quantities at $>500 \mathrm{~km}$ from the Borderland. For the calculation we assume $\mathrm{Nd} / \mathrm{Hf}=7.2$ [Willbold and Stracke, 2006] for the SAS and FAS representative compositions, and we use the $\mathrm{Nd}$ abundance of sample 13 combined with the isotopic values of sample 10 for FAS. Background data from Georoc (http://georoc.mpch-mainz.gwdg.de/georoc/).

[23] Although close in composition to $\mathrm{C}$, the three eruptive stages of Jasper Seamount show distinct fields in $\mathrm{Pb}, \mathrm{Sr}, \mathrm{Nd}$, and $\mathrm{Hf}$ isotope space (Figures 5-6). The FTS (red) has the most radiogenic Sr isotope signatures, combined with the least radiogenic $\mathrm{Nd}$, $\mathrm{Hf}$, and $\mathrm{Pb}$. The second group, FAS (blue), has the most radiogenic $\mathrm{Pb}$ isotope signature but intermediate $\mathrm{Nd}, \mathrm{Sr}$, and $\mathrm{Hf}$. This group plots near the side of $\mathrm{C}$ closest to the least extreme samples of St. Helena and the Austral Islands (Figures 5-6). The samples closely match the composition of Opal Seamount and Guadalupe Island [Sun, 1980] (Figures 5-6). The identical signatures in three individual volcanoes show that the uniformity of the FAS composition is not simply an artifact of sampling. The third group,
SAS (green), has the most radiogenic $\mathrm{Nd}$ and $\mathrm{Hf}$ isotope signatures, combined with the least radiogenic $\mathrm{Sr}$ and intermediate $\mathrm{Pb}$ isotope signatures. This group lies near $\mathrm{C}$ and overlaps with Pacific MORB and the near-ridge seamounts. These nearridge seamounts, whether from our own or other data sets [Davis et al., 1995, 2002], define a field that does not include FTS or FAS in ${ }^{208} \mathrm{~Pb} /{ }^{204} \mathrm{~Pb}$ or ${ }^{207} \mathrm{~Pb} /{ }^{204} \mathrm{~Pb}$ versus ${ }^{206} \mathrm{~Pb} /{ }^{204} \mathrm{~Pb}$ (Figures 5-6).

\section{Discussion}

[24] The geology and geochemistry of seamounts in and around FGST provide us with clues as to their origin in terms of which source regions and melting processes were involved in their formation. 
Below, we briefly discuss (1) the mantle source regions of near-ridge seamounts and (2) compare the eruptive stage of FGST with other OIVs, Hawaii in particular. We then (3) investigate whether Hawaiian melting models may also explain smaller volcanoes, since a successful model will place tighter constraints on the geodynamic processes that play an essential role. Finally (4), we

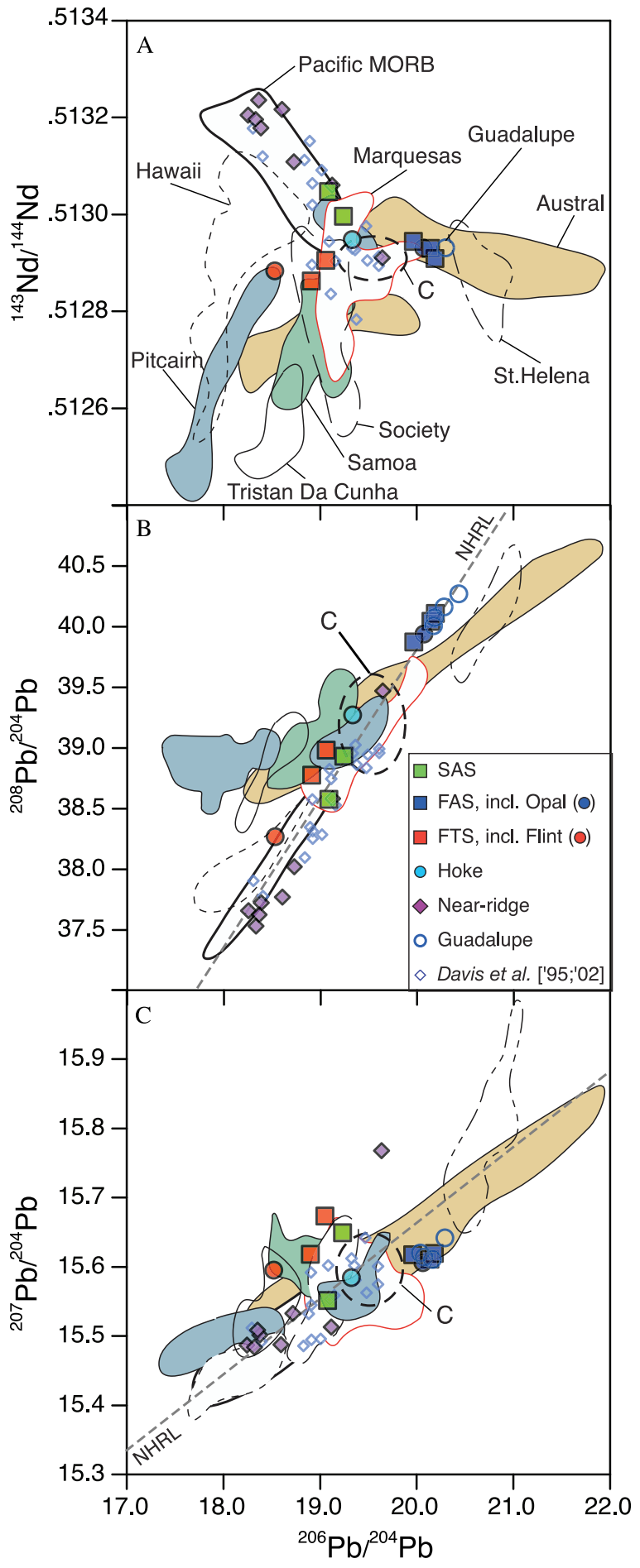

place the modeling results in the context of the detailed observations of Jasper Seamount volcanic stages and evaluate the processes involved.

\subsection{Origin of Near-Ridge Seamounts}

[25] The isotopic compositions of the small, nearridge seamounts in the FGST region fall between the most depleted MORB-mantle end-member and C [e.g., Zindler et al., 1984; Hanan and Graham, 1996]. Their flat-topped morphology and similarity in rock types with MORB seamounts, combined with their isotopic composition within the fields of Pacific MORB and near ridge Pacific seamounts (Figures 5-6) [Niu et al., 2002], suggest these seamounts may have formed in a (near-) MOR setting [Batiza and Vanko, 1984]. Although the evidence is somewhat circumstantial, this interpretation only requires MOR processes which we know occurred. A similar composition was erupted by elongated seamounts closer to the fossil trench and the Continental Borderland (Figure 1). Their young ages suggest that plate boundary deformation has reactivated these seamounts [Davis et al., 1995, 2002]. These authors considered it most likely that extension related to the direction of least compressive stress of the current San Andreas transform plate boundary [Atwater and Severinghaus, 1989; Lonsdale, 1991] caused shallow melting. Therefore, both near-ridge and reactivated seamounts likely sample the same source and provide some insight into the composition of the lithosphere and upper mantle directly beneath the FGST.

[26] The origin of tholeiites and alkali basalts in MOR-seamounts was explained by variable

Figure 6. $\mathrm{Pb}$ and $\mathrm{Nd}$ isotope compositions (symbols as in Figure 5). (a) ${ }^{206} \mathrm{~Pb} /{ }^{204} \mathrm{~Pb}$ versus ${ }^{143} \mathrm{Nd} /{ }^{144} \mathrm{Nd}$ shows that the three clusters of eruptive stages of Jasper Seamount cannot be explained by binary mixing, since FAS is not intermediate between FTS and SAS. Therefore, at least three source components are required, that all lie on different sides of C. Near-ridge seamounts display a continuous field between $\mathrm{C}$ and depleted MORB. (b) ${ }^{206} \mathrm{~Pb} /{ }^{204} \mathrm{~Pb}$ versus ${ }^{208} \mathrm{~Pb} /{ }^{204} \mathrm{~Pb}$ shows that all samples from Jasper Seamount plot slightly above NHRL suggesting slightly isotopically enriched compositions. (c) In ${ }^{207} \mathrm{~Pb} /{ }^{204} \mathrm{~Pb}$ versus ${ }^{206} \mathrm{~Pb} /{ }^{204} \mathrm{~Pb}$ it is clear that FAS and FTS do not overlap with the near-ridge seamounts (purple and blue open diamonds). The low ${ }^{207} \mathrm{~Pb} /{ }^{204} \mathrm{~Pb}$ relative to ${ }^{206} \mathrm{~Pb} /{ }^{204} \mathrm{~Pb}$ of the FAS may be due to recent $\mathrm{U} / \mathrm{Pb}$ fractionation and subsequent ingrowth. Background data from Georoc (http://georoc.mpchmainz.gwdg.de/georoc/). 

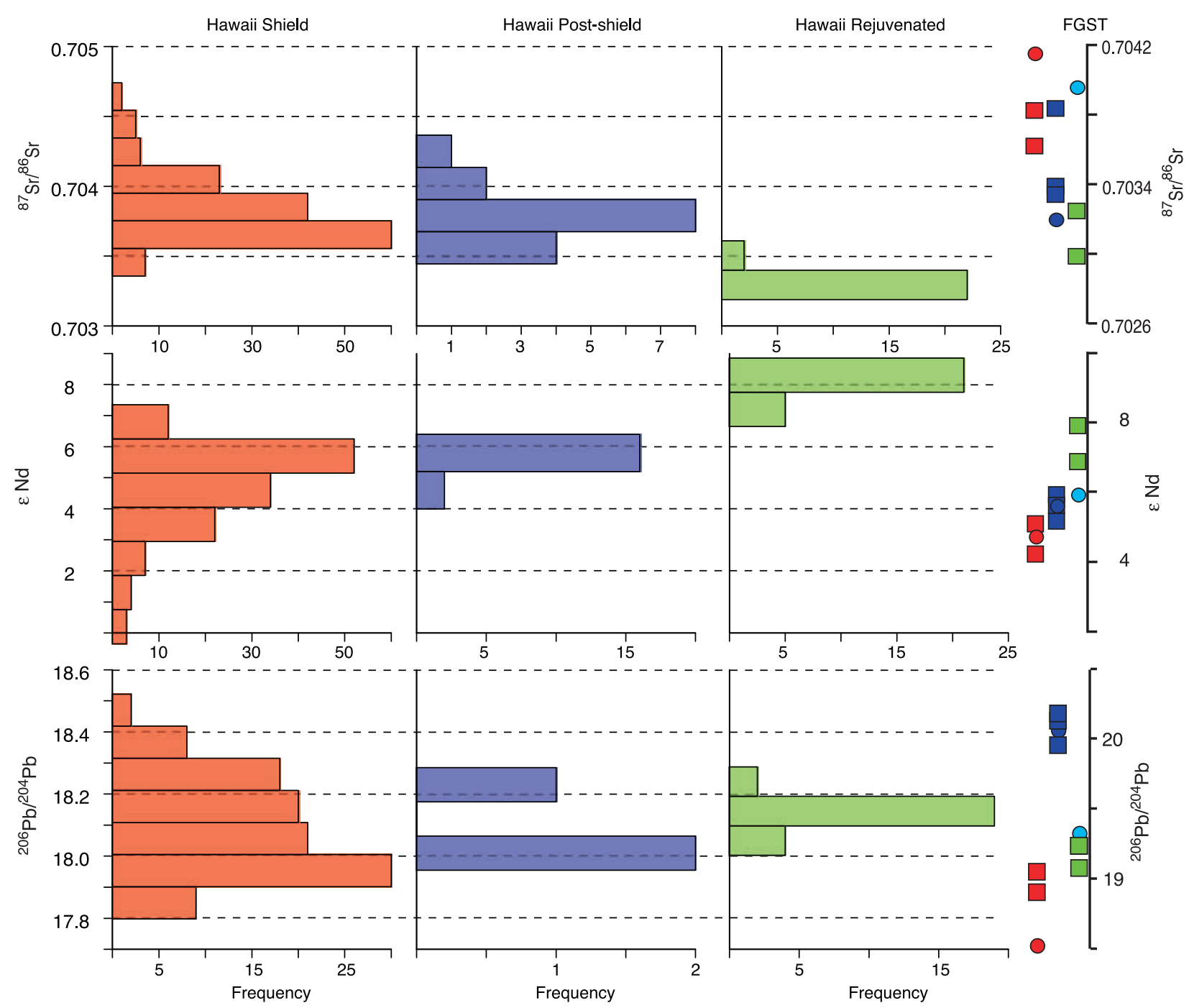

Figure 7. Isotopic compositions of samples from stages of Jasper Seamount compared to Hawaiian volcanic stages (symbols as in Figure 5). Histograms for stages of Loa-trend volcanoes (data compiled by Tanaka et al. [2008]) show a shift in compositions for the majority of samples: from shield to postshield and rejuvenated stages, the compositions of the majority of samples become less radiogenic in $\mathrm{Sr}$ isotopes, more radiogenic in $\mathrm{Nd}$ isotopes, and the mode of the $\mathrm{Pb}$ isotope histograms shifts to slightly more radiogenic $\mathrm{Pb}$ isotopes. The $\mathrm{Pb}$ isotope compositions also show the highest values for FAS. Since FAS is intermediate between FTS and SAS in Nd and Sr isotopes, but an extreme in $\mathrm{Pb}$, at least three difference mantle source components are required.

degrees of partial melting and/or less melt aggregation of a heterogeneous MORB mantle [Zindler et al., 1984; Fornari et al., 1988; Graham et al., 1988; Niu et al., 2002]. It is interesting to note that the small seamounts, which were formed just off the MOR-axis, isotopically trend toward C [e.g., Zindler et al., 1984; Niu et al., 2002], and the melts with the most enriched trace element signatures are closer to $\mathrm{C}$ (less depleted) than the underlying MORB crust. Thus, the compositional range and rock types of the near-ridge seamounts correspond well to small MOR-type seamounts. The extensional seamounts of Davis et al. [1995, 2002] are compositionally indistinguishable from MOR-type seamounts. However, our near-ridge seamount group lacks the NE-SW elongation of the extensional seamounts making a MOR origin more likely.

\subsection{Comparison Between Jasper Seamount and Other OIVs}

[27] Jasper seamount resembles other moderate and large sized OIVs in its construction in stages that are distinct in time, elemental abundance patterns, and isotopic compositions. Chemical and isotopic 

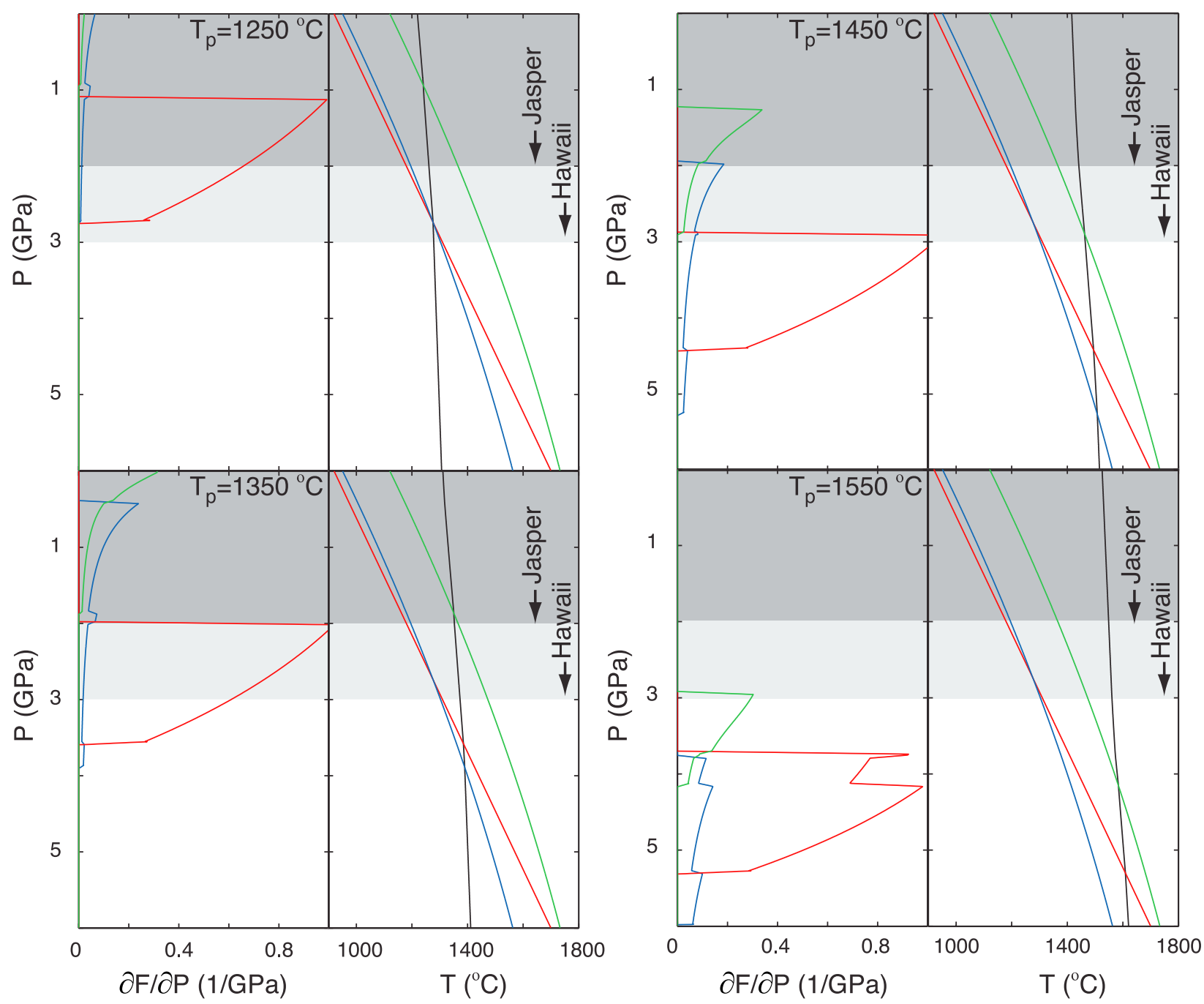

Figure 8. Melt productivity functions for different source lithologies as a function of temperature and pressure. Functions were calculated following Ito and Mahoney [2005], using their lithologies, proportions, and solidi. Each panel shows, on the right, the calculated path followed by a parcel of mantle material in pressure-temperature space with a black line crossing the solidi of the different source lithologies (wet peridotite in blue, pyroxenite in red, and dry peridotite in green). The left side of each panel shows the corresponding melt productivity functions. At a starting potential temperature (prior to melting) of $1550^{\circ} \mathrm{C}$ all three lithologies will melt significantly below the lithosphere under both Hawaii and Jasper Seamount (shown as a light and dark gray area, respectively), while at $1450^{\circ} \mathrm{C}$ only the pyroxenite melts below the Hawaiian lithosphere and both the pyroxenite and the wet peridotite melt below the lithosphere of Jasper Seamount. In the case of $1350^{\circ} \mathrm{C}$ only pyroxenite melts below the lithosphere in both cases, while at $1250^{\circ} \mathrm{C}$ only partial melting of the pyroxenite takes place under the lithosphere of Jasper.

compositions in these OIV stages are interpreted in terms of melting conditions and sampled mantle source components. This is the case for moderate sized OIVs [e.g., Hoernle and Schmincke, 1993; Maaloe, 1998; Geldmacher et al., 2001; Paul et al., 2005], as well as the unusually large Hawaiian OIVs [e.g., Clague and Dalrymple, 1987; Frey et al., 1990]. Since Hawaii is probably the most intensely studied OIV, it plays a major role in OIV models and discussions. Hawaiian OIVs show a characteristic life cycle of four major stages where mantle melting waxes and wanes, both in terms of total volumes of melt produced and in terms of the actual degree of melting of their mantle source [Stearns, 1940; Macdonald and Katsura, 1964; Macdonald, 1968; Moore et al., 1982; Clague and Dalrymple, 1987; Frey et al., 1990]. The geological evolution of the modestly sized Jasper Seamount corresponds well to the stages found in Hawaii, with FTS as the shield stage, FAS as the postshield stage, and SAS as the rejuvenated stage [Gee et al. 1991]. Modeling of 
seafloor and rock magnetic data and geochronological data are also consistent with some volcanic quiescence between FAS and SAS [Gee et al., 1988; Pringle et al., 1991].

[28] There are also some important similarities in the evolution of isotopic compositions of the individual stages. For example, the FTS is the most isotopically enriched in terms of $\mathrm{Nd}$ and $\mathrm{Sr}$ isotopic compositions, while the SAS is the most depleted. Similarly, in Hawaii there is a shift from shield lavas where the majority is isotopically enriched to late stage lavas that are on average more depleted (Figure 7) [Stille et al., 1983; Staudigel et al., 1984; Roden et al., 1994; Valbracht et al., 1996; Mukhopadhyay et al., 2003; Fekiacova et al., 2007]. This isotopic evolution from more enriched early lavas to later and more depleted compositions has also been recognized in other, more moderately sized islands, such as the Societies, Mauritius, and Pitcairn [Woodhead, 1992; White and Duncan, 1996; Paul et al., 2005].

[29] This similarity in isotopic evolution with enriched stage compositions that are distinct from MORBs suggests a common origin for the generation of these volcanoes. This origin may lie in a melting process that samples several mantle components sequentially, which is a hypothesis we explore in section 7.3. One of these components was sampled by three different volcanoes of FGST, and the isotopic composition in these volcanoes is identical (FAS-Jasper Seamount, Opal Seamount, Guadalupe Island). Therefore, the commonality in isotopic evolution of the individual stages, the distinction from MORB and the persistence of the FAS signature together provide key constraints on the origin. In addition, the age progression and the difference in volcano morphology with surrounding seamounts, suggest that a plume origin such as proposed for Hawaii, could be consistent with FGST and Jasper Seamount in particular.

[30] There are, however, some small differences between Hawaii and Jasper Seamount. For example, Jasper Seamount shows a larger range in crystal fractionation for the final rejuvenated stage (SAS), and overall more transitional lavas in FTS compared to Hawaiian shield tholeiites. In addition, the larger proportion of gabbroic xenoliths relative to peridotites in SAS compared to Hawaii, combined with petrogenetic modeling, suggests shallower-level magma storage during this stage for Jasper Seamount than for Hawaii [Gee et al., 1991]. Furthermore, there is no perfect match between the isotopic compositions of the develop- mental stages of Jasper Seamount and Hawaii. Therefore, the overall origin is likely the same, but in detail there are differences in the tectonic setting and small differences in the source composition that result in these minor differences.

[31] Beyond a broad-scale comparison, we can investigate whether recent melting models for Hawaii could explain volcanoes the size of Jasper Seamount. In the following section we investigate such models and assess what additional constraints can be placed on the processes responsible for OIV construction, based on observations at Jasper Seamount.

\subsection{Comparing Melting in Hawaii and Jasper Seamount}

[32] Models aiming to explain the relationship between elemental abundances and isotopic compositions of individual Hawaiian stages initially involved two-component plume-lithosphere mixing, requiring metasomatism of one of the components by melts of the other component [Chen and Frey, 1983, 1985; Roden et al., 1984; Clague and Dalrymple, 1988; Reiners and Nelson, 1998]. This two-component concept satisfies constraints from $\mathrm{Sr}$ and $\mathrm{Nd}$ isotope and trace element compositions but not $\mathrm{Pb}$ isotope compositions, requiring more than two components to explain the compositional range of Hawaiian lavas [Roden et al., 1984]. In fact, Hawaiian volcanism in the last few million years occurred in the parallel Kea and Loa chains of volcanoes whose shields are isotopically distinct, hence requiring at least three or four distinct components in the mantle source [e.g., Abouchami et al., 2005; Fekiacova et al., 2007]. The commonly assumed isotopic mantle components Kea, Koolau (or Makapuu), and Loihi, with possibly a depleted component for the rejuvenated lavas [e.g., Eisele et al., 2003; Regelous et al., 2003; Fekiacova et al., 2007, and references therein], have been coupled to elemental abundances in more recent melting models. In addition to changes in degree of melting [e.g., Frey et al., 1990], different lithologies with different solidi may be responsible for some abundance variations. For example, the high $\mathrm{SiO}_{2}$, high $\mathrm{Ni}$, and low $\mathrm{Ca}$ characteristics of Hawaiian shield lavas cannot be explained with simple peridotite melting, and instead a pyroxenite component may be present [e.g., Pertermann and Hirschmann, 2003; Sobolev et al., 2005]. Melting such different lithologies at different depths has already been invoked by a number of workers [e.g., Lassiter and Hauri, 1998; Huang 
et al., 2005; Salters et al., 2006; Fekiacova et al., 2007] to construct a more accurate model than the initial binary mixing model.

[33] Melting of different lithological components has recently been modeled numerically by Ito and Mahoney [2005] and Bianco et al. [2005]. These models describe the melting of different lithologies with the melting models of Phipps Morgan and Morgan [1999] and Phipps Morgan [2001]. The models of Ito and Mahoney [2005] and Bianco et al. [2005] are dynamic numerical models that incorporate sequential melting of three melting lithologies: a pyroxenite, a wet enriched peridotite, and a dry depleted peridotite. A key feature of these models is the high melt productivity of the pyroxenite, overwhelming (and suppressing) peridotite melts [Phipps Morgan, 2001; Ito and Mahoney, 2005]. In the case of Hawaii, varying amounts of the pyroxenite would constitute the Koolau component and explain its elemental abundances [Tanaka et al., 2008]. The shield stage would likely end due to the exhaustion of the pyroxenite component [Fekiacova et al., 2007], followed by dominance of peridotite melting. Subsequently, melting of a depleted component may cause the rejuvenated stage [e.g., Mukhopadhyay et al., 2003; Fekiacova et al., 2007]. In modeling, the assignment of geochemical signatures to source lithologies [e.g., Bianco et al., 2005] is one of the many under-constrained parameters, but it provides a quantitative tool to investigate the concept of successive melting of different lithologies.

[34] Such an approach can be applied to any OIV source region including Jasper Seamount despite its much smaller size. Following the example of Ito and Mahoney [2005] and Bianco et al. [2005], we can construct melt productivity functions and investigate the effects of different pressure-temperature conditions. While a fully dynamic melting model is not the aim of this paper, we can nevertheless examine the melting functions. We use the same melting equations and the same three general lithologies used in the dynamic model of Ito and Mahoney [2005]. Our melting functions are constructed by stepping through a range in pressure (6-0 GPa), while calculating the temperature and melting functions at each step, closely matching the productivity functions in their model. The resulting productivity functions are sensitive to a number of parameters (e.g., relative proportions of the components, mineral modes of the components, exact melting curves, and latent heat of fusion between peridotites and pyroxenite), but these are poorly constrained, leading us to focus on changes in the more tractable potential temperature and lithospheric thickness. Different lithospheric thicknesses limit melting ( $\sim 3$ and $\sim 2 \mathrm{GPa}$, respectively) [Turcotte and Schubert, 1982; Regelous et al., 2003] while potential temperature determines when melting starts.

[35] Melt productivity calculations for different potential temperatures (different panels in Figure 8) and different lithospheric thicknesses (light and dark gray areas in Figure 8) show that productivity depths of the three lithologies shift with respect to the lithosphere and each other (Figure 8). If melting of the last-melting, dry peridotite (function in green) is to generate rejuvenated lavas away from the plume axis as expected from the typical age difference with shields [Bianco et al., 2005], the rejuvenated component should not produce any significant melts before reaching the lithosphere. This means that in the case of Hawaii a starting potential temperature between 1450 and $1550^{\circ} \mathrm{C}$ can produce the observed erupted series, while in the case of Jasper Seamount the temperature is more likely to lie between 1350 and $1450^{\circ} \mathrm{C}$. This agrees well with the predicted difference in excess temperature of $\sim 150^{\circ} \mathrm{C}$ [Putirka, 2008], assuming buoyancy fluxes for Hawaii and Jasper (Guadalupe) from Courtillot et al. [2003]. The suggested difference in buoyancy flux is likely also important for the difference in erupted volumes between the two settings.

[36] The buoyancy flux under Hawaii is estimated at $8700 \mathrm{~kg} / \mathrm{s}$, while Guadalupe in the same chain as Jasper Seamount only has $300 \mathrm{~kg} / \mathrm{s}$ [Courtillot et al., 2003]. The estimate for Guadalupe was rated "poor" and may not be representative for the smaller Jasper Seamount. In fact, halving the Guadalupe plume flux $(150 \mathrm{~kg} / \mathrm{s})$ for Jasper Seamount constitutes a perfect scaling between the difference in flux and the difference in volume between Jasper and Hawaii ( $\sim 60$ times). The crude scaling of plume fluxes with volcano volumes and with the consistency of the predicted potential temperatures lend some broad support for this general model of sequential melting of different components. In detail, the productivity curves in Figure 8 suggest that there will be minor differences between both settings in terms of the start and end of melting of particular components and the capping of the melting column by the lithosphere. These minor differences would result in, for example, small differences in the total amount of melt extracted. However, these differences are 
sensitive to changes in the assumed input parameters, which could reasonably be adjusted to fine tune the fit (e.g., fractions of components, mineral modes).

[37] The isotopic compositions of the different stages seem distinct between the stages, suggesting that the melts that are produced at different depths need to be extracted without equilibration with the remaining source components. Since the overlap in productivity with depth of the different components is minimal (Figure 8), any mixing of melts would not produce extensive mixing arrays. Extraction of melts without source equilibration is possible in channelized flow, where channels may exist at $1-10^{2} \mathrm{~m}$ spacing [Spiegelman and Kelemen, 2003]. Disequilibrium between the different components can be maintained as long as the melt flows in channels within $10^{2}-10^{4} \mathrm{~m}$ of transport [Spiegelman and Kenyon, 1992; Spiegelman et al., 2001]. Therefore, as long as the melts are extracted in high-porosity channels, melts of the different components can be delivered to the crust. Combined with slightly sheared flow of the upwelling material due to plate motion, the location of shield-stage eruptions which is limited by pyroxenite melting can be laterally separated from the shallower melting post-shield component (similar to Kurz et al. [1995]).

\subsection{Stage Compositions and the Melting Model}

[38] The calculations above show that sequentially melting different source lithologies as has been proposed for Hawaii is a feasible model for Jasper Seamount. In Hawaii, the different lithologies have been assigned specific isotopic mantle source compositions, and below we briefly review these and compare them to the compositions found in Jasper Seamount. In addition, we assess the impact on interpretations by the observations at Jasper Seamount, while keeping in mind the limits of our small data set.

\subsubsection{Rejuvenated Stage and SAS}

[39] The rejuvenated lavas in Hawaii contain the lowest $\mathrm{Pb}$ and $\mathrm{Sr}$, and the highest $\mathrm{Nd}$ and $\mathrm{Hf}$ isotope ratios, and require the presence of a depleted component in the mantle source [e.g., Mukhopadhyay et al., 2003; Fekiacova et al., 2007]. These lavas are also characterized by enriched trace element patterns. This combination has led to a suggested origin by metasomatism of either the lithosphere beneath Hawaii or a recycled lithospheric component in the plume [e.g., Reiners and Nelson, 1998; Lassiter et al., 2000; Shafer et al., 2005; Yang et al., 2003; Frey et al., 2005; Fekiacova et al., 2007].

[40] Os isotope compositions have been used to argue that all melting and metasomatism likely occurred within the lithosphere [Lassiter et al., 2000]. The positive correlation of Os isotopes with other radiogenic isotopes such as $\mathrm{Sr}$ in the shield lavas was argued to reflect the Os isotope signature of the plume. This signature cannot explain the Os isotope composition of rejuvenated lavas, which include the most radiogenic ratios, and these lavas are therefore unlikely to be formed by metasomatism of the lithosphere by shield-stage melts. On the basis of similar compositions in Hawaiian lithospheric xenoliths and a correlation of Os isotopes with major elements, Lassiter et al. [2000] argue that rejuvenated lavas were likely formed by melts from lithospheric material. The enriched trace element concentrations led these authors to suggest that Os-major element correlations stem from pyroxenite melting, while the trace element enrichment results from a contribution of peridotite melts.

[41] Derivation of rejuvenated lavas from strictly Pacific lithosphere, however, does not agree with $\mathrm{Pb}$ isotope compositions, which show that Pacific MORB and ODP (843) samples of $100 \mathrm{Ma}$ old lithosphere are different from the rejuvenated lavas [Fekiacova et al., 2007]. Therefore, the rejuvenated lavas require some input from a mantle component slightly different than Pacific lithosphere. In fact, other studies have suggested that ancient recycled lithosphere is required to explain Os and Hf isotope systematics of xenoliths from the Kaau-Pali-Kalihi group [Griselin and Lassiter, 2001; Bizimis et al., 2004]. In other words, a mantle melt is likely involved in creating the rejuvenated lavas, but the requirement of producing time-integrated low ${ }^{87} \mathrm{Sr} /{ }^{86} \mathrm{Sr}$, high ${ }^{143} \mathrm{Nd} /{ }^{144} \mathrm{Nd}$, and enriched trace elements leaves us with two possibilities. This melt composition may be produced from melting a mantle component with an EMORB source composition, although the EMORB of Sun and McDonough [1989] is less enriched than the rejuvenated lavas of Hawaii and SAS. Alternatively, an origin involving melting of a metasomatized component that recently was enriched in its trace element concentrations, and with so far insignificant radiogenic ingrowth, is another option [e.g., Reiners and Nelson, 1998; Lassiter et al., 2000; Shafer et al., 
2005; Yang et al., 2003; Freyet al., 2005; Fekiacova et al., 2007].

[42] Our data set is not extensive enough to identify trends in an in-depth evaluation of the origin of the enriched trace element-depleted isotope composition of SAS without invoking major assumptions. Instead, given the same unique combination of enriched trace element and depleted isotope compositions (Figures 4 and 7) [e.g., Yang et al., 2003; Fekiacova et al., 2007] we adopt the oftenproposed "recent metasomatism" model for Hawaii, although an ad hoc assumption of an EMORB source with just the right composition remains possible. An origin for the metasomatized component could be average upper mantle enriched by melts either at the MOR or from a mantle plume (similar to the metasomatized lithosphere of Lassiter et al. [2000]), although $\mathrm{Pb}$ isotope data [Fekiacova et al., 2007] may be best explained with an asthenospheric metasomatizing agent. Melting of either such a metasomatized source or an EMORB source would have to correspond to melting of the last-melting peridotite in our multiple component melting model. Recent models for the peridotite solidus include a rough estimation of the effect of varying $\mathrm{Na}_{2} \mathrm{O}+\mathrm{K}_{2} \mathrm{O}$ content [Hirschmann, 2000]. However, that does not (yet) allow for a precise definition of solidi for volatile-rich versus metasomatized sources, corresponding to the two peridotite components in our model. Irrespective of the suitability of the metasomatized source for our model, it is not well established what actually triggers melting after volcanic quiescence.

[43] Melt extraction during the rejuvenated stage may be triggered by the following processes: (1) Lithospheric thinning by an underlying plume [Gurriet, 1987; Liu and Chase, 1991] causes decompression melting of a nonexhausted component. (2) Lithospheric flexure in response to the construction of a new volcano could cause decompression under the flexural bulge around the new volcano, explaining rejuvenated and Arch lavas [ten Brink and Brocher, 1987; Bianco et al., 2005].

[44] In evaluating lithospheric thinning as an origin, it is important to realize that Jasper Seamount is likely caused by a much weaker plume than Hawaii [Courtillot et al., 2003]. Therefore, the upwelling pattern in the mantle will be more sheared, with lithospheric erosion much further downstream from the main upwelling [Thoraval et al., 2006]. This will cause a much longer volcanic quiescence between the postshield and rejuvenated stages compared to Hawaii, since erosion would take place several hundred kilometers further downstream. Instead volcanic quiescence at Jasper lasts at most $0.2 \mathrm{Ma}$ longer [Pringle et al., 1991], which corresponds to at most $16 \mathrm{~km}$ further downstream $(80 \mathrm{~km} / \mathrm{Ma}$ for plate motion). In addition, thinning does not directly predict volcanic quiescence or related Arch volcanism [Bianco et al., 2005]. This leaves the flexure model as a possibility.

[45] In order to evaluate the flexural model we need to investigate whether Jasper Seamount lies on the flexural bulge of the younger Opal Seamount. Assuming a line load [Turcotte and Schubert, 1982] and elastic plate thickness of $\sim 12 \mathrm{~km}$ [Calmant and Cazenave, 1987], and using Young's modulus and Poisson ratio of Bianco et al. [2005] (70 GPa, 0.25 ), suggests that the highest point in the flexural bulge should be at about $82 \mathrm{~km}$. This is very close to the distance between Opal and Jasper Seamount (Figure 1). We do not have the sample suite to confirm that Opal Seamount was indeed actively growing at the same time as SAS erupted, but it is reasonable to assume that the younger Opal Seamount would not have gone extinct substantially before Jasper Seamount. Besides the distance to the flexural bulge, its amplitude should be evaluated since it should generate decompression melts. Assuming again a line load flexural model, using elastic thicknesses of 12 and $30 \mathrm{~km}$ and volumes of 700 and $30,000 \mathrm{~km}^{3}$ for Jasper Seamount and Hawaii, suggests the flexural amplitude should be about $20 \%$ of that of Hawaii. However, without modeling melting coupled to flexure to assess the produced amount of melt [e.g., Bianco et al., 2005], we cannot evaluate whether flexure can produce the required volume of melt for SAS.

[46] Two other processes with a proposed relation to rejuvenated volcanism can also be assessed. Since Jasper Seamount is not exposed to subaerial erosion, it is unlikely to provide a cause of decompression through rebounding [Paul and White, 2002]. Second, the lack of large landslide blocks surrounding Jasper Seamount suggests that mass wasting is not a likely trigger for rejuvenation either [Presley et al., 1997].

\subsubsection{Postshield Stage and FAS}

[47] Nearly all Hawaiian postshield lavas contain the Kea component (exceptions being those from Kahoolawe and Hualalai [e.g., Xu et al., 2007]). This component has intermediate ${ }^{206} \mathrm{~Pb} /{ }^{204} \mathrm{~Pb}, \mathrm{Sr}$, $\mathrm{Nd}$, and $\mathrm{Hf}$ isotope ratios, plus lower $\Delta 7 / 4 \mathrm{~Pb}$ and 
higher $\Delta 8 / 4 \mathrm{~Pb}$, relative to the classic HIMU endmember [Zindler and Hart, 1986]. These isotope characteristics are very similar to those of the C composition defined by Hanan and Graham [1996] based on a comparison of MORBs and OIVs from around the globe, although with slightly high ${ }^{206} \mathrm{~Pb} /{ }^{204} \mathrm{~Pb}$ (Figure 6). Other individual ocean island localities can also have these " $\mathrm{C}$ " characteristics, such as the postshield lavas on Gran Canaria, Canary Islands [Hoernle et al., 1991]. U-Th-Pb fractionation during Archean subduction may be responsible for the origin of HIMU. However, simple HIMU-MORB mixing does not readily account for the $\mathrm{C}$ composition; instead, younger parent-daughter fractionation (several hundreds of Ma) is likely responsible [Hanan and Graham, 1996; Thirlwall, 1997]. This was also proposed previously as a possible origin for the Kea component in Hawaii [Hanan and Graham, 1996; Thirlwall, 1997; Eisele et al., 2003]. This particular isotopic signature can therefore be interpreted as young recycled oceanic lithosphere ("young HIMU") based on mixing assessments, including $\mathrm{Pb}$ and $\mathrm{Sr}$ isotopes and trace element ratios [Thirlwall, 1997].

\subsubsection{Shield Stage and FTS}

[48] Hawaiian shield lavas either contain a discernable amount of the Koolau component, or they are more similar to the Kea component, depending on whether they are part of the Loa or Kea chain of volcanoes, respectively. The Koolau component displays the most radiogenic $\mathrm{Sr}$, and least radiogenic $\mathrm{Nd}$, $\mathrm{Hf}$, and $\mathrm{Pb}$ isotope compositions. This component is present as variable amounts of the EMI mantle end-member, generated either by recycled pelagic sediments, ancient depleted lithosphere or an ancient basaltic component [Stille et al., 1983; Roden et al., 1984; Lassiter and Hauri, 1998; Blichert-Toft et al., 1999; Salters et al., 2006; Huang et al., 2005]. However, the FTS lavas of Jasper Seamount are closer in composition to the Kea component.

[49] A small difference between FTS and Mauna Kea lavas is expressed in overlapping, but ranging to higher ${ }^{206} \mathrm{~Pb} /{ }^{204} \mathrm{~Pb},{ }^{207} \mathrm{~Pb} /{ }^{204} \mathrm{~Pb}, \mathrm{Sr}$, and lower $\mathrm{Nd}$ isotope composition in FTS (e.g., $\sim 18.5-19.1$ versus $\sim 18.1-18.7 ; \sim 15.6-15.7$ versus $\sim 15.5$; $\sim 0.7036-0.7042$ versus $\sim 0.7032-0.7041$; $\sim 4.5-5.3$ versus $\sim 5-8.5 \varepsilon$ [Eisele et al., 2003; Tanaka et al., 2008]). Although FTS is much less isotopically enriched than shields with the Koolau component, the isotopic differences with the Kea component suggest a small isotopic enrichment in
FTS compared to Kea. The small size of our data set limits investigations of mixing, and it is therefore difficult to constrain which isotopically enriched component may have mixed into the source. However, we do point out that sediment assimilation is unlikely to explain the observed signature. Assuming sediment assimilation by either FAS or SAS compositions (details in Figure 5), known to be present in the Jasper source, we can construct mixing curves. Mixtures with GLOSS [Plank and Langmuir, 1998; Chauvel et al., 2008] show mixing lines that curve around the FTS samples, due to the sediment $\mathrm{Nd} / \mathrm{Hf}$ ratio. Since we deem it unlikely that the samples we analyzed are all outliers, only a mixture with continental platform sandstones [Chauvel et al., 2008] passes between the FTS samples. However, it is improbable that substantial amounts of such sandstones would be present $>500 \mathrm{~km}$ away from the Continental Borderland. Therefore, the slightly isotopically enriched signature of FTS is likely a source signature.

\subsection{Constraints Provided by Jasper Seamount}

[50] The similar progression through lithologically and isotopically distinct stages between Jasper Seamount and other OIVs can be explained with the same melting model as proposed for Hawaii. Moreover, Jasper Seamount observations place additional constraints on the processes operating during OIV construction. Jasper Seamount and these OIVs share key observations such as chain linearity, age progression, and a characteristic geochemical evolution. However, some of the major differences also placing constraints are the thinner lithosphere and the smaller erupted volumes and related buoyancy flux. The most important interpretation resulting from this suggests rejuvenation is consistent but may not require lithospheric flexure. This interpretation and the melting model provide two testable hypotheses. The applicability of the melting model can be tested in other volcanoes, by examining whether shield stage lavas have major element compositions that agree with derivation from pyroxenite melting (similar to Sobolev et al. [2005]). It is important to remember for such studies that the melt productivity of other components does not always equal zero, suggesting some peridotite contribution is possible. The flexural model may be tested by investigating the geochemical evolution and the effect of different sized volcanoes for similar aged (thickness) lithosphere or the geochemical evolution of similar 
sized volcanoes for lithosphere of different age (thickness). We therefore suggest that it is important to continue studying the systematics of melting behavior and source region compositions in order to test the proposed melting model. On the longterm a larger OIV data set may provide the critical constraints needed to narrow down processes at the origin of distinct geochemical signatures and help understand the geodynamic origin of different types of OIV volcanoes in terms of a plume or extension origin [e.g., Courtillot et al., 2003].

\section{Conclusions}

[51] Seamounts in and around the FGST offer a unique opportunity to explore both near-ridge MOR volcanoes and small OIVs that have many of the characteristics of larger ocean island volcanoes. The MOR-type seamounts can be distinguished from the FGST through their size, morphology, and chemical and isotopic compositions. Their compositions invariably lie within the Pacific MORB array, between $C$ and depleted MORB, consistent with a MORB-type source composition.

[52] The OIV volcanoes of the FGST show three chronologically and compositionally distinct stages of volcanic activity. The isotopic compositions of the different stages suggest a heterogeneous source with at least three distinct components. None of these three source components require extreme end-members and instead fall close to $\mathrm{C}$. The youngest series (SAS) plot near $\mathrm{C}$, the intermediate age FAS plot on the side of $\mathrm{C}$ near the least extreme Austral and St. Helena compositions, and the oldest series (FTS) is slightly isotopically enriched compared to $\mathrm{C}$. The isotopic compositions for these individual stages have some similarities with compositions in Hawaiian volcanic stages.

[53] The similarities in age progression, isotopic evolution, and the success of explaining these different sized features with the same melting model suggest that a geodynamic origin such as proposed for Hawaii is possible. We show that sequential melting based on source lithology-controlled solidi of distinct components in a heterogeneous source is consistent with our observations and therefore may explain similar melting sequences in OIVs despite drastically different melt volumes. Such a model allows a similar stage-wise melt extraction as in Hawaii, but with different lithospheric thickness and potential temperature controlling actual melt productivity with depth.
This specific stage-wise progression of isotopically enriched to depleted compositions combined with quantitative modeling offers one of the more promising explanations for OIV melting processes and may help distinguish between plume and extension-dominated OIVs.

\section{Acknowledgments}

[54] We thank Alice Davis for providing a sample from Flint Seamount. Other samples were obtained through the funding of NSF and University of California ship funds. We thank Jeff Gee and James Natland for sharing unpublished major element data. Marcel Regelous, Vincent Salters, and two anonymous reviewers are thanked for their constructive reviews that substantially improved this manuscript. Bridget Smith and Tyrone Rooney are thanked for their reviews of earlier versions of this work. Joan Miller provided assistance in the SDSU isotope lab. JBT acknowledges financial support from the French Institut National des Sciences de l'Univers. The isotope work at SDSU was made possible by NSF and Keck grants to $\mathrm{BBH}$.

\section{References}

Abouchami, W., A. W. Hofmann, S. J. G. Galer, F. A. Frey, J.Eisele, and M. Feigenson(2005), Lead isotopes reveal bilateral asymmetry and vertical continuity in the Hawaiian mantle plume, Nature, 434, 851-856, doi:10.1038/nature03402.

Allègre, C. J., S. R. Hart, and J. F. Minster (1983), Chemical structure and evolution of the mantle and continents determined by inversion of $\mathrm{Nd}$ and $\mathrm{Sr}$ isotopic data: II. Numerical experiments and discussion, Earth Planet. Sci. Lett., 66, 191-213, doi:10.1016/0012-821X(83)90136-X.

Atwater, T., and J. Severinghaus (1989), Tectonic maps of the northeast Pacific, in The Eastern Pacific Ocean and Hawaii, Geol. of N. Am., vol. N, edited by E. L. Winterer, pp. 15-20, Geol. Soc. of Am., Boulder, Colo.

Bargar, K. E., and E. D. Jackson (1974), Calculated volumes of individual shield volcanoes along the Hawaiian-Emperor chain, U.S. Geol. Surv. J. Res., 2, 545-550.

Batiza, R. (1977), Oceanic crustal evolution: Evidence from the petrology and geochemistry of isolated oceanic central volcanoes, 295 pp., Univ. of Calif., San Diego.

Batiza, R., and D. Vanko (1984), Petrology of Pacific seamounts, J. Geophys. Res., 89, 11,235-11,260, doi:10.1029/ JB089iB13p11235.

Batiza, R., T. J. Bernatowicz, C. M. Hohenberg, and F. A. Podosek (1979), Relations of noble gas abundances to petrogenesis and magmatic evolution of some basalts and related differentiated volcanic rocks, Contrib. Mineral. Petrol., 69, 301-313, doi:10.1007/BF00372332.

Bianco, T. A., G. Ito, J. M. Becker, and M. O. Garcia (2005), Secondary Hawaiian volcanism formed by flexural arch decompression, Geochem. Geophys. Geosyst., 6, Q08009, doi:10.1029/2005GC000945.

Bizimis, M., J. C. Lassiter, V. J. M. Salters, G. Sen, and M. Griselin (2004), Extreme Hf-Os isotope compositions in Hawaiian peridotites xenoliths: Evidence for an ancient recycled lithosphere, Eos Trans. AGU, 85(47), Fall Meet. Suppl., Abstract V51B-550. 
Blichert-Toft, J., F. A. Frey, and F. Albarède (1999), Hf isotopic compositions of the Hawaii Scientific Drilling Project core and the source mineralogy of Hawaiian basalts, Geophys. Res. Lett., 26, 935-938, doi:10.1029/ 1999GL900110.

Calmant, S., and A. Cazenave (1987), Anomalous elastic thickness of the oceanic lithosphere in the south-central Pacific, Nature, 328, 236-238, doi:10.1038/328236a0.

Castillo, P., and R. Batiza (1989), Strontium, neodymium and lead isotope constraints on near-ridge seamount production beneath the South Atlantic, Nature, 342, 262-265, doi: $10.1038 / 342262 \mathrm{a} 0$

Castillo, P. R., P. A. Floyd, and C. France-Lanord (1992), Isotope geochemistry of Leg 129 basalts: Implications for the origin of the widespread Cretaceous volcanic event in the Pacific, Proc. Ocean Drill. Program, Sci. Results, 129, 405-513.

Chauvel, C., E. Lewin, M. Carpentier, N. T. Arndt, and J.-C. Marini (2008), Role of recycled oceanic basalt and sediment in generating the Hf-Nfd mantle array, Nat. Geosci., 1, 6467, doi:10.1038/ngeo.2007.51.

Chen, C. Y., and F. A. Frey (1983), Origin of Hawaiian tholeiite and alkali basalt, Nature, 302, 785-789, doi:10.1038/ 302785a0.

Chen, C. Y., and F. A. Frey (1985), Trace-element and isotopic geochemistry of lavas from Haleakala Volcano: East Maui, Hawaii: Implications for the origin of Hawaiian basalts, J. Geophys. Res., 90, 8743-8768, doi:10.1029/ JB090iB10p08743.

Cheng, Q., K.-H. Park, J. D. MacDougall, A. Zindler, G. W. Lugmair, J. Hawkins, P. Lonsdale, and H. Staudigel (1987), Isotopic evidence for a hotspot origin of the Louisville seamount chain, in Seamounts, Islands and Atolls, Geophys. Monogr. Ser., vol. 43, edited by B. H. Keating et al., pp. 283-296, AGU, Washington, D.C.

Clague, D. A., and G. B. Dalrymple (1987), The HawaiianEmperor volcanic chain, Part I: Geological evolution, in Volcanism in Hawaii, U.S. Geol. Surv. Prof. Pap., 1350(1), edited by R. Decker et al., pp. 5-54, U.S. Govt. Print. Off., Washington, D. C.

Clague, D. A., and G. B. Dalrymple (1988), Age and petrology of alkalic postshield and rejuvenated-stage lavas from Kauai, Hawaii, Contrib. Mineral. Petrol., 99, 202-218, doi:10.1007/BF00371461.

Condie, K. C. (1993), Chemical composition and evolution of the upper continental crust: Contrasting results from surface samples and shales, Chem. Geol., 104, 1-37, doi:10.1016/ 0009-2541(93)90140-E.

Courtillot, V., A. Davaille, J. Besse, and J. Stock (2003), Three distinct types of hotspots in the Earths mantle, Earth Planet. Sci. Lett., 205, 295-308, doi:10.1016/S0012821X(02)01048-8.

Davis, A. S., S. H. Gunn, W. A. Bohrson, L.-B. Gray, and J. R. Hei (1995), Chemically diverse, sporadic volcanism at seamounts offshore southern and Baja California, Geol. Soc. Am. Bull., 107, 554-570, doi:10.1130/00167606(1995) $107<0554:$ CDSVAS $>2.3 . C O ; 2$.

Davis, A. S., D. A. Clague, W. A. Bohrson, G. B. Dalrymple, and H. G. Greene (2002), Seamounts at the continental margin of California: A different kind of oceanic intraplate volcanism, Geol. Soc. Am. Bull., 114, 316-333, doi:10.1130/00167606(2002)114<0316:SATCMO >2.0.CO;2.

Eisele, J., W. Abouchami, S. J. G. Galer, and A. W. Hofmann (2003), The $320 \mathrm{kyr} \mathrm{Pb}$ isotope evolution of Mauna Kea lavas recorded in the HSDP-2 drill core, Geochem. Geophys. Geosyst., 4(5), 8710, doi:10.1029/2002GC000339.
Fekiacova, Z., W. Abouchami, S. J. G. Galer, M. O. Garcia, and A. W. Hofmann (2007), Origin and temporal evolution of Koolau Volcano, Hawaii: Inferences from isotope data on the Koolau Scientific Drilling Project (KSDP), the Honolulu Volcanics and ODP Site 843, Earth Planet. Sci. Lett., 261, 65-83, doi:10.1016/j.epsl.2007.06.005.

Fornari, D. J., M. R. Perfit, J. F. Allan, R. Batiza, R. Haymon, A. Barone, W. B. F. Ryan, T. Smith, T. Simkin, and M. A. Luckmann (1988), Geochemical and structural studies of the Lamont seamounts: Seamounts as indicators of mantle processes, Earth Planet. Sci. Lett., 89, 63-83, doi:10.1016/ 0012-821X(88)90033-7.

Frey, F. A., W. S. Wise, M. O. Garcia, III, H. West, S.-T. Kwon, and A. Kennedy (1990), Evolution of Mauna Kea Volcano, Hawaii: Petrologic and geochemical constraints on postshield volcanism, J. Geophys. Res., 95, 12711300, doi:10.1029/JB095iB02p01271.

Frey, F. A., et al. (2000), Origin and evolution of a submarine large igneous province: The Kerguelen Plateau and Broken Ridge, southern Indian Ocean, Earth Planet. Sci. Lett., 176, 73-89, doi:10.1016/S0012-821X(99)00315-5.

Frey, F. A., S. Huang, J. Blichert-Toft, M. Regelous, and M. Boyet (2005), Origin of depleted components in basalt related to the Hawaiian hot spot: Evidence from isotopic and incompatible element ratios, Geochem. Geophys. Geosyst., 6, Q02L07, doi:10.1029/2004GC000757.

Gee, J., L. Tauxe, J. A. Hildebrand, H. Staudigel, and P. Lonsdale (1988), Nonuniform magnetization of Jasper Seamount, J. Geophys. Res., 93, 12,159-12,175, doi:10.1029/ JB093iB10p12159.

Gee, J., H. Staudigel, and J. H. Natland (1991), Geology and Petrology of Jasper Seamount, J. Geophys. Res., 96, 40834105, doi:10.1029/90JB02364.

Geldmacher, J., K. Hoernle, P. van den Bogaard, G. Zank1, and D. Garbe-Schonberg (2001), Earlier history of the $\geq 70$-Ma-old Canary hotspot based on temporal and geochemical evolution of the Selvagen Archipelago and neighboring seamounts in the eastern North Atlantic, J. Volcanol. Geotherm. Res., 111, 55-87, doi:10.1016/S0377. 0273(01)00220-7.

Graham, D. W., A. Zindler, M. D. Kurz, W. J. Jenkins, R. Batiza, and $\mathrm{H}$. Staudigel (1988), $\mathrm{He}, \mathrm{Pb}, \mathrm{Sr}$ and $\mathrm{Nd}$ isotope constraints on magma genesis and mantle heterogeneity beneath young Pacific seamounts, Contrib. Mineral. Petrol., 99, 446-463, doi:10.1007/BF00371936.

Griselin, M., and J. Lassiter (2001), Extreme unradiogenic Os isotopes in Hawaiian mantle xenoliths: Evidence for preservation of ancient melt-depleted domains in the convecting upper mantle, Eos Trans. AGU, 82(47), Fall Meet. Suppl., Abstract V21D-08.

Gurriet, P. (1987), A thermal model for the origin of posterosional alkalic lava, Hawaii, Earth Planet. Sci. Lett., 82, 153-158, doi:10.1016/0012-821X(87)90115-4.

Hammer, P. T. C., J. A. Hildebrand, and R. L. Parker (1991), Gravity inversion using seminorm minimization: Density modeling of Jasper Seamount, Geophysics, 56, 68-79, doi:10.1190/1.1442959.

Hammer, P. T. C., L. M. Dorman, J. A. Hildebrand, and B. D. Cornuelle (1994), Jasper Seamount structure: Seafloor seismic refraction tomography, J. Geophys. Res., 99, 6731-6752, doi:10.1029/93JB02170.

Hanan, B. B., and D. W. Graham (1996), Lead and Helium isotope evidence from oceanic basalts for a common deep source of mantle plumes, Science, 272, 991-995, doi:10.1126/science.272.5264.991 
Hart, S. R., E. H. Hauri, L. A. Oschmann, and J. A. Whitehead (1992), Mantle plumes and entrainment: Isotopic evidence, Science, 256, 517-520, doi:10.1126/science.256.5056.517.

Hart, S. R., M. Coetzee, R. K. Workman, J. Blusztajn, K. T. M. Johnson, J. M. Sinton, B. Steinberger, and J. W. Hawkins (2004), Genesis of the Western Samoa seamount province: Age, geochemical fingerprint and tectonics, Earth Planet. Sci. Lett., 227, 37-56, doi:10.1016/j.epsl.2004.08.005.

Hauff, F., K. Hoernle, and A. Schmidt (2003), Sr-Nd-Pb composition of Mesozoic Pacific oceanic crust (site 1149 and 801, ODP Leg 185), Implications for alteration of ocean crust and the input into the Izu-Bonin-Mariana subduction system, Geochem. Geophys. Geosyst., 4(8), 8913, doi:10.1029/2002GC000421.

Hildebrand, J. A., L. M. Dorman, P. T. C. Hammer, A. E. Schreiner, and B. D. Cornuelle (1989), Seismic tomography of Jasper Seamount, Geophys. Res. Lett., 16, 1355-1358, doi:10.1029/GL016i012p01355.

Hirschmann, M. M. (2000), Mantle solidus: Experimental constraints and the effects of periodite composition, Geochem. Geophys. Geosyst., 1(10), 1042, doi:10.1029/2000GC000070.

Hoernle, K., and H.-U. Schmincke (1993), The petrology of the Tholeiites through melilite nephelinites on Gran Canaria, Canary Islands: Crystal fractionation, accumulation, and depths of melting, J. Petrol., 34, 573-597.

Hoernle, K., G. Tilton, and H.-U. Schmincke (1991), Sr-Nd-Pb isotopic evolution of Gran Canaria: Evidence for shallow enriched mantle beneath the Canary Islands, Earth Planet. Sci. Lett., 106, 44-63, doi:10.1016/0012-821X(91)90062-M.

Hofmann, A. W. (1997), Mantle geochemistry: The message from oceanic volcanism, Nature, 385, 219-229, doi:10.1038/385219a0.

Huang, S., F. A. Frey, J. Blichert-Toft, R. V. Fodor, G. R. Bauer, and G. Xu (2005), Enriched components in the Hawaiian plume: Evidence from Kahoolawe Volcano, Hawaii, Geochem. Geophys. Geosyst., 6, Q11006, doi:10.1029/2005GC001012.

Ielsch, G., M. Caroff, H. G. Barsczus, R. C. Maury, H. Guillou, G. Guille, and J. Cotton (1998), Géochimie des basaltes de lîle de Ua Huka (archipel des Marquises): Variation du taux de fusion partielle et hétérogénéité de la source mantellique, $C$. R. Acad. Sci., Ser. IIa Sci. Terre Planets, 326, 413-420.

Irvine, T. N., and W. R. A. Baragar (1971), A guide to the chemical classification of the common volcanic rocks, Can. J. Earth Sci., 8, 523-548.

Ito, G., and J. J. Mahoney (2005), Flow and melting of a heterogeneous mantle: 1 . Method and importance to the geochemistry of ocean island and mid-ocean ridge basalts, Earth Planet. Sci. Lett., 230, 29-46, doi:10.1016/j.epsl.2004. 10.035 .

Jarrard, J. D., and D. A. Clague (1977), Implications of Pacific Islands and seamount ages for the origin of volcanic chains, Rev. Geophys. Space Phys., 15, 57-76, doi:10.1029/ RG015i001p00057.

Koppers, A. A. P., H. Staudigel, D. M. Christie, J. J. Dieu, and M. S. Pringle (1995), Sr-Nd-Pb isotope geochemistry of Leg 144 west Pacific guyots: Implications for the geochemical evolution of the "SOPITA" mantle anomaly, Proc. Ocean Drill. Program, Sci. Results, 144, 535-545.

Koppers, A. A. P., J. Phipps Morgan, J. W. Morgan, and $2 \mathrm{H}$. Staudigel (2001), Testing the fixed hotspot hypothesis using ${ }^{40} \mathrm{Ar}{ }^{39} \mathrm{Ar}$ age progressions along seamount trails, Earth Planet. Sci. Lett., 185, 237-252, doi:10.1016/S0012821X(00)00387-3.

Koppers, A. A. P., H. Staudigel, M. S. Pringle, and J. R. Wijbrans (2003), Short-lived and discontinuous intraplate volcanism in the South Pacific: Hot spots or extensional volcanism?, Geochem. Geophys. Geosyst., 4(10), 1089, doi:10.1029/2003GC000533.

Kurz, M. D., T. C. Kenna, D. Kammer, J. M. Rhodes, and M. Garcia (1995), Isotopic evolution of Mauna Loa volcano: A view from the submarine southwest rift, in Mauna Loa Volcano Revealed: Structure, Composition, History and Hazards, Geophys. Monogr. Ser., vol. 92, edited by J. M. Rhodes and J. P. Lockwood, pp. 289-306, AGU, Washington, D. C.

Lassiter, J. C., and E. H. Hauri (1998), Osmium-isotope variations in Hawaiian lavas: Evidence for recycled oceanic lithosphere in the Hawaiian plume, Earth Planet. Sci. Lett., 164, 483-496, doi:10.1016/S0012-821X(98)00240-4.

Lassiter, J. C., E. H. Hauri, P. W. Reiners, and M. O. Garcia (2000), Generation of Hawaiian post-erosional lavas by melting of a mixed lherzolite/pyroxenite source, Earth Planet. Sci. Lett., 178, 269-284, doi:10.1016/S0012-821X(00)00084-4.

Le Bas, M. J., R. W. Le Maitre, A. Streckeisen, and B. Zanettin (1986), A chemical classification of volcanic rocks based on the total alkali-silica diagram, J. Petrol., 27, 745-750.

Legendre, C., R. C. Maury, D. Savanier, J. Cotten, C. Chauvel, C. Hémond, C. Bollinger, G. Guille, S. Blais, and P. Rossi (2005), The origin of intermediate and evolved lavas in the Marquesas archipelago: An example from Nuku Hiva island (French Polynesia), J. Volcanol. Geotherm. Res., 143, $293-$ 317, doi:10.1016/j.jvolgeores.2004.12.001.

Liu, M., and C. G. Chase (1991), Evolution of Hawaiian basalts: A hotspot melting model, Earth Planet. Sci. Lett., 104, 151-165, doi:10.1016/0012-821X(91)90201-R.

Lonsdale, P. (1991), Structural patterns of the Pacific floor offshore of peninsular California, in The Gulf and Peninsular Province of the Californias, edited by J. P. Dauphin et al., AAPG Mem., 47, 87-125.

Luhr, J. F., J. J. Aranda-Gómez, and T. B. Housh (1995), San Quintín Volcanic Field, Baja California Norte, México: Geology, petrology, and geochemistry, J. Geophys. Res. 100, 10,353-10,380, doi:10.1029/95JB00037.

Maaloe, S. (1998), Melt dynamics of a layered mantle plume source, Contrib. Mineral. Petrol., 133, 83-95, doi:10.1007/ s004100050439.

Macdonald, G. A. (1968), Composition and origin of Hawaiian lavas, in Studies in Volcanology, Geol. Soc. Am. Mem., vol. 116, edited by R. E. Coats et al., pp. 477-522, Geol. Soc. of Am., Boulder, Colo.

Macdonald, G. A., and T. Katsura (1964), Chemical composition of Hawaiian lavas, J. Petrol., 5, 82-133.

McDonough, W. F., and S.-S. Sun (1995), Composition of the Earth, Chem. Geol., 120, 223-253, doi:10.1016/00092541(94)00140-4.

Moore, J. G., D. A. Clague, and W. R. Normark (1982), Diverse basalt types from Loihi Seamount, Hawaii, Geology, 10, 88-92, doi:10.1130/0091-7613(1982)10<88:DBTFLS $>2.0$.CO;2

Morgan, W. J. (1971), Convection plumes in the lower mantle, Nature, 230, 42-43, doi:10.1038/230042a0.

Mukhopadhyay, S., J. C. Lassiter, K. A. Farley, and S. W. Bogue (2003), Geochemistry of Kauai shield-stage lavas: Implications for the chemical evolution of the Hawaiian plume, Geochem. Geophys. Geosyst., 4(1), 1009, doi:10.1029/ 2002GC000342.

Niu, Y., M. Regelous, I. J. Wendt, R. Batiza, and M. J. OHara (2002), Geochemistry of near-EPR seamounts: Importance of source vs. process and the origin of enriched mantle component, Earth Planet. Sci. Lett., 199, 327-345, doi:10.1016/ S0012-821X(02)00591-5.

Paul, D., and W. M. White (2002), Geochemistry and volcanic evolution of Mauritius, Eos Trans. AGU, 83(47), Fall Meet. Suppl., Abstract S11A-1131. 
Paul, D., W. M. White, and J. Blichert-Toft (2005), Geochemistry of Mauritius and the origin of rejuvenescent volcanism on oceanic island volcanoes, Geochem. Geophys. Geosyst., 6, Q06007, doi:10.1029/2004GC000883.

Pertermann, M., and M. M. Hirschmann (2003), Anhydrous partial melting experiments on MORB-like eclogite: Phase relations, phase compositions and mineral-melt partitioning of major elements at 2-3GPa, J. Petrol., 44, 2173-2201, doi:10.1093/petrology/egg074.

Phipps Morgan, J. (2001), Thermodynamics of pressure release melting of a veined plum pudding mantle, Geochem. Geophys. Geosyst., 2(4), 1001, doi:10.1029/2000GC000049.

Phipps Morgan, J., and W. J. Morgan (1999), Two-stage melting and the geochemical evolution of the mantle: A recipe for mantle plum-pudding, Earth Planet. Sci. Lett., 170, $215-$ 239, doi:10.1016/S0012-821X(99)00114-4.

Plank, T., and C. H. Langmuir (1998), The chemical composition of subducting sediment: Implications for the crust and mantle, Chem. Geol., 145, 325-394, doi:10.1016/S00092541(97)00150-2.

Presley, T. K., J. M. Sinton, and M. Pringle (1997), Postshield volcanism and catastrophic mass wasting of the Waianae Volcano, Oahu, Hawaii, Bull. Volcanol., 58, 597-616, doi: $10.1007 / \mathrm{s} 004450050165$.

Pringle, M. S. (1992), Geochronology and petrology of the Musicians seamounts, and the search of hotspot volcanism in the Cretaceous Pacific, Univ. of Hawaii, Honolulu.

Pringle, M. S., H. Staudigel, and J. Gee (1991), Jasper Seamount: Seven million years of volcanism, Geology, 19, 364-368, doi:10.1130/0091-7613(1991)019<0364:JSSMYO>2.3. $\mathrm{CO} ; 2$

Putirka, K. (2008), Excess temperatures at ocean islands: Implications for mantle layering and convection, Geology, 36, 283286, doi:10.1130/G24615A.1

Regelous, M., A. W. Regelous, W. Abouchami, and S. J. G. Galer (2003), Geochemistry of lavas from the Emperor Seamounts, and the geochemical evolution of Hawaiian magmatism from 85 to $42 \mathrm{Ma}$, J. Petrol., 44, 113-140, doi:10.1093/petrology/44.1.113.

Reiners, P. W., and B. K. Nelson (1998), Temporalcompositional-isotopic trends in rejuvenated-stage magmas of Kauai, Hawaii, and implications for mantle melting processes, Geochim. Cosmochim. Acta, 62, 2347-2368, doi:10.1016/ S0016-7037(98)00141-0.

Roden, M. F., F. A. Frey, and D. A. Clague (1984), Geochemistry of tholeiitic and alkalic lavas from the Koolau range, Oaho, Hawaii: Implications for Hawaiian volcanism, Geochim. Cosmochim. Acta, 58, 1431-1440.

Roden, M. F., T. Trull, S. R. Hart, and F. A. Frey (1994), New $\mathrm{He}, \mathrm{Nd}, \mathrm{Pb}$, and $\mathrm{Sr}$ isotopic constraints on the constitution of the Hawaiian plume: Results from Koolau Volcano, Oahu, Hawaii, USA, Geochim. Cosmochim. Acta, 58, 1431-1440, doi:10.1016/0016-7037(94)90547-9.

Salters, V., J. Blichert-Toft, Z. Fekiacova, A. Sachi-Kocher, and M. Bizimis (2006), Isotope and trace element evidence for depleted lithosphere in the source of enriched Koolau basalts, Contrib. Mineral. Petrol., 151, 297-312, doi:10.1007/s00410-005-0059-y.

Shafer, J. T., C. R. Neal, and M. Regelous (2005), Petrogenesis of Hawaiian postshield lavas: Evidence from Nintoku Seamount, Emperor Seamount Chain, Geochem. Geophys. Geosyst., 6, Q05L09, doi:10.1029/2004GC000875.

Shimizu, N., and S. R. Hart (1973), Differential dissolution technique (DDT): Chemical separation of crystals from glass, Year Book Carnegie Inst. Washington, 72, 268-270.
Shimizu, N., and S. R. Hart (1982), Application of the ion microprobe to geochemistry and cosmochemistry, Annu. Rev. Earth Planet. Sci., 10, 483-526, doi:10.1146/annurev. ea.10.050182.002411

Smith, W. H. F., and D. T. Sandwell (1997), Global sea floor topography from satellite altimetry and ship depth soundings, Science, 277, 1956-1962, doi:10.1126/science.277. 5334.1956

Sobolev, A. V., A. W. Hofmann, S. V. Sobolev, and I. K. Nikogosian (2005), An olivine-free mantle source of Hawaiian shield basalts, Nature, 434, 590-597, doi:10.1038/ nature 03411 .

Spiegelman, M., and P. B. Kelemen (2003), Extreme chemical variability as a consequence of channelized melt transport, Geochem. Geophys. Geosyst., 4(7), 1055, doi:10.1029/ 2002GC000336.

Spiegelman, M., and P. Kenyon (1992), The requirements for chemical disequilibrium during magma migration, Earth Planet. Sci. Lett., 109, 611-620, doi:10.1016/0012821X(92)90119-G.

Spiegelman, M., P. B. Kelemen, and E. Aharonov (2001), Causes and consequences of flow organization during melt transport: The reaction infiltration instability in compactible media, J. Geophys. Res., 106, 2061-2077, doi:10.1029/ 2000JB900240.

Staudigel, H., A. Zindler, S. R. Hart, T. Leslie, C.-Y. Chen, and D. Clague (1984), The isotopic systematics of a juvenile intraplate volcano: $\mathrm{Pb}, \mathrm{Nd}$, and $\mathrm{Sr}$ isotope ratios of basalts from Loihi Seamount, Hawaii, Earth Planet. Sci. Lett., 69, 13-29, doi:10.1016/0012-821X(84)90071-2.

Staudigel, H., K.-H. Park, M. S. Pringle, J. L. Rubenstone, W. H. F. Smith, and A. Zindler (1991), The longevity of the south Pacific isotope and thermal anomaly, Earth Planet. Sci. Lett., 102, 24-44, doi:10.1016/0012-821X(91)90015-A.

Stearns, H. T. (1940), Four-phase volcanism in Hawaii, Geol. Soc. Am. Bull., 51, 1947-1948.

Stille, P., D. M. Unruh, and M. Tatsumoto (1983), Pb, Sr, $\mathrm{Nd}$ and $\mathrm{Hf}$ isotopic evidence of multiple sources for Oahu, Hawaii basalts, Nature, 304, 25-29, doi:10.1038/ $304025 \mathrm{a} 0$.

Storey, M., G. Rogers, A. D. Saunders, and D. J. Terrel (1989), San Quintín Volcanic Field, Baja California, México: 'Withinplate magmatism following ridge subduction, Terra Nova, 1 , 195-202, doi:10.1111/j.1365-3121.1989.tb00352.x.

Sun, S.-S. (1980), Lead isotopic study of young volcanic rocks from mid-oceanic ridges, ocean islands and island arcs, Philos. Trans. R. Soc. London, Ser. A, 297, 409-445, doi:10.1098/ rsta. 1980.0224

Sun, S.-S., and W. F. McDonough (1989), Chemical and isotopic systematics of oceanic basalts: Implications for mantle composition and processes, in Magmatism in the Ocean Basins, edited by A. D. Saunders and M. J. Norry, Geol. Soc. London Spec. Publ., 42, 313-345.

Tanaka, R., A. Makishima, and E. Nakamura (2008), Hawaiian double volcanic chain triggered by an episodic involvement of recycled material: Constraints from temporal $\mathrm{Sr}-\mathrm{Nd}-\mathrm{Hf}-\mathrm{Pb}$ isotopic trend of the Loa-type volcanoes, Earth Planet. Sci. Lett., 265, 450-465, doi:10.1016/j.eps1.2007.10.035.

ten Brink, U. S., and T. M. Brocher (1987), Multichannel seismic evidence for a subcrustal intrusive complex under Oahu and a model for Hawaiian volcanism, J. Geophys. Res., 92, 13,687-13,707, doi:10.1029/JB092iB13p13687.

Thirlwall, M. F. (1997), Pb isotopic and elemental evidence for OIB derivation from young HIMU mantle, Chem. Geol., 139, 51-74, doi:10.1016/S0009-2541(97)00033-8. 
Thoraval, C., A. Tommasi, and M.-P. Doin (2006), Plumelithosphere interaction beneath a fast moving plate, Geophys. Res. Lett., 33, L01301, doi:10.1029/2005GL024047.

Turcotte, D. L., and G. Schubert (1982), Geodynamics: Applications of Continuum Physics to Geological Problems, 1st ed., 456 pp., Wiley, New York.

Valbracht, P. J., H. Staudigel, M. Honda, I. McDougall, and G. R. Davies (1996), Isotopic tracing of volcanic source regions from Hawaii: Decoupling of gaseous from lithophile magma components, Earth Planet. Sci. Lett., 144, 185-198, doi:10.1016/0012-821X(96)00126-4.

White, W. M., and R. A. Duncan (1996), Geochemistry and Geochronology of the Society Islands: New Evidence for Deep Mantle Recycling, in Earth Processes: Reading the Isotopic Code, Geophys. Monogr. Ser., vol. 95, edited by A. Basu and S. R. Hart, pp. 183-206, AGU, Washington, D. C.

Willbold, M., and A. Stracke (2006), Trace element composition of mantle end-members: Implications for recycling of oceanic and upper and lower continental crust, Geochem. Geophys. Geosyst., 7, Q04004, doi:10.1029/2005GC001005.

Woodhead, J. D. (1992), Temporal geochemical evolution in oceanic intra-plate volcanics: A case study from the Marquesas (French Polynesia) and comparison with other hotspots, Contrib. Mineral. Petrol., 111, 458-467, doi:10.1007/ BF00320901.
Workman, R. K., S. R. Hart, M. Jackson, M. Regelous, K. A. Farley, J. Blusztajn, M. Kurz, and H. Staudigel (2004), Recycled metasomatized lithosphere as the origin of the Enriched Mantle II (EM2) end-member: Evidence from the Samoan Chain, Geochem. Geophys. Geosyst., 5, Q04008, doi:10.1029/2003GC000623.

Wright, E., and W. M. White (1987), The origin of Samoa: New evidence from $\mathrm{Sr}, \mathrm{Nd}$, and $\mathrm{Pb}$ isotopes, Earth Planet. Sci. Lett., 81, 151-162, doi:10.1016/0012-821X(87)90152-X.

Xu, G., F. A. Frey, D. A. Clague, W. Abouchami, J. BlichertToft, B. Cousens, and M. Weisler (2007), Geochemical characteristics of West Molokai shield-and postshield-stage lavas: Constraints on Hawaiian plume models, Geochem. Geophys. Geosyst., 8, Q08G21, doi:10.1029/2006GC001554.

Yang, H.-J., F. A. Frey, and D. A. Clague (2003), Constraints on the source components of lavas forming the Hawaiian North Arch and Honolulu Volcanics, J. Petrol., 44, 603627, doi:10.1093/petrology/44.4.603.

Zindler, A., and S. R. Hart (1986), Chemical geodynamics, Annu. Rev. Earth Planet. Sci., 14, 493-571, doi:10.1146/ annurev.ea.14.050186.002425.

Zindler, A., H. Staudigel, and R. Batiza (1984), Isotope and trace element geochemistry of young Pacific seamounts: Implications for the scale of upper mantle heterogeneity, Earth Planet. Sci. Lett., 70, 175-195, doi:10.1016/0012821X(84)90004-9. 